\title{
Evaluation of local and systemic immune responses in pigs experimentally challenged with porcine reproductive and respiratory syndrome virus
}

\author{
Salik Nazki ${ }^{1 \dagger}$, Amina Khatun ${ }^{1,2+}$, Chang-Gi Jeong ${ }^{1 \dagger}$, Sameer ul Salam Mattoo ${ }^{3}$, Suna Gu ${ }^{3}$, Sim-In Lee ${ }^{1}$, \\ Seung-Chai Kim', Ji-Hyo Park', Myoun-Sik Yang ${ }^{1}$, Bumseok Kim', Choi-Kyu Park ${ }^{4}$, Sang-Myeong Lee ${ }^{3 *}$ \\ and Won-II Kim ${ }^{1 *}$ (1)
}

\begin{abstract}
The host-associated defence system responsible for the clearance of porcine reproductive and respiratory syndrome virus (PRRSV) from infected pigs is currently poorly understood. To better understand the dynamics of host-pathogen interactions, seventy-five of 100 pigs infected with PRRSV-JA142 and 25 control pigs were euthanized at 3, 10, 21, 28 and 35 days post-challenge (dpc). Blood, lung, bronchoalveolar lavage (BAL) and bronchial lymph node (BLN) samples were collected to evaluate the cellular immune responses. The humoral responses were evaluated by measuring the levels of anti-PRRSV IgG and serum virus-neutralizing (SVN) antibodies. Consequently, the highest viral loads in the sera and lungs of the infected pigs were detected between 3 and $10 \mathrm{dpc}$, and these resulted in moderate to mild interstitial pneumonia, which resolved accompanied by the clearance of most of the virus by $28 \mathrm{dpc}$. At peak viremia, the frequencies of alveolar macrophages in infected pigs were significantly decreased, whereas the monocytederived DC/macrophage and conventional DC frequencies were increased, and these effects coincided with the early induction of local T-cell responses and the presence of proinflammatory cytokines/chemokines in the lungs, BAL, and BLN as early as $10 \mathrm{dpc}$. Conversely, the systemic T-cell responses measured in the peripheral blood mononuclear cells were delayed and significantly induced only after the peak viremic stage between 3 and $10 \mathrm{dpc}$. Taken together, our results suggest that activation of immune responses in the lung could be the key elements for restraining PRRSV through the early induction of T-cell responses at the sites of virus replication.
\end{abstract}

*Correspondence: leesangm@jbnu.ac.kr; kwi0621@jbnu.ac.kr

'Salik Nazki, Amina Khatun and Chang-Gi Jeong contributed equally to this study

${ }^{1}$ College of Veterinary Medicine, Jeonbuk National University, lksan,

South Korea

${ }^{3}$ Division of Biotechnology, Advanced Institute of Environment and Bioscience, College of Environmental \& Biosource Science, Jeonbuk National University, Iksan, South Korea

Full list of author information is available at the end of the article

\section{Introduction}

Porcine reproductive and respiratory syndrome virus (PRRSV), a single-stranded positive-sense RNA virus with an approximate 15.4-kb genome, belongs to the genus Betaarterivirus of the family Arteriviridae (ICTV 2018). In pigs, PRRSV causes porcine reproductive and respiratory syndrome (PRRS), which is characterized by reproductive failure in breeding sows and severe respiratory distress in young and growing pigs [1]. PRRS results in colossal economic losses in the swine industry worldwide, and these losses are still observed three decades

c) The Author(s) 2020. This article is licensed under a Creative Commons Attribution 4.0 International License, which permits use, sharing, adaptation, distribution and reproduction in any medium or format, as long as you give appropriate credit to the original author(s) and the source, provide a link to the Creative Commons licence, and indicate if changes were made. The images or other third party material in this article are included in the article's Creative Commons licence, unless indicated otherwise in a credit line to the material. If material is not included in the article's Creative Commons licence and your intended use is not permitted by statutory regulation or exceeds the permitted use, you will need to obtain permission directly from the copyright holder. To view a copy of this licence, visit http://creativeco mmons.org/licenses/by/4.0/. The Creative Commons Public Domain Dedication waiver (http://creativecommons.org/publicdomain/ zero/1.0/) applies to the data made available in this article, unless otherwise stated in a credit line to the data. 
after its emergence in the United States and Europe. After the exposure of pigs to PRRSV, the virus replicates in alveolar macrophages (AM) and further spreads rapidly throughout the body via a lymphohematic route. This viral spread results in acute infection characterized by viremia that lasts for approximately 1 month [2], and a few studies have reported a nonviremic persistent infection of secondary lymphoid tissues lasting for approximately 150 days or longer [3]. In general, the viremia peaks at approximately 7-10 days post-infection (dpi) and is almost cleared by 28 dpi depending on the viral strain and age of the pigs $[4,5]$. Additionally, the immune response against PRRSV depends on the strain, but the virus usually has immunosuppressive properties $[4,5]$, which leads to the increased susceptibility of pigs to secondary microbial infections [6]. The interactions between PRRSV and host immune responses have been widely studied, but most studies investigated systemic immune responses using PBMC and/or serum [7]. Previous studies have shown that interstitial pneumonia constitutes the major lung lesions in PRRSV-infected pigs and that significantly decreased numbers of alveolar macrophages are found in bronchoalveolar lavage (BAL) and lung parenchyma samples from PRRSV-infected pigs [8]. However, to the best of our knowledge, the kinetics of local immune responses in the lungs or lymph nodes during the course of infection compared with those of peripheral immune responses have not been previously studied. This information would provide a more in-depth understanding of the sequential activation of both immune compartments and the correlation between local or peripheral immune responses and virus clearance in infected pigs. As a result, achieving a comprehensive understanding of the immune responses against PRRSV infection remains an important goal in PRRSV research.

During PRRSV infection, the pig immune system is capable of escalating an immune response to ultimately clear the virus from the body [9]. For clearance, proper stimulation of the pig innate immune system is required to direct the development of protective adaptive immunity against PRRSV. Interestingly, the preferential sites for PRRSV replication are alveolar macrophages present in the lungs, which form the major component of the respiratory DC/macrophage network. This network is predominantly involved in sensing foreign antigens, controlling inflammation, and initiating the adaptive immune response [10]. Different DC subsets with specific functional specializations exist in the respiratory $\mathrm{DC} /$ macrophage network in the lungs and are reportedly resistant to PRRSV infection $[8,11]$. However, upon activation, these DC travel to lymphoid tissues to present antigen to $\mathrm{T}$ lymphocytes and thereby serve as the link between innate and adaptive immunity $[10,11]$.
$\mathrm{T}$ cells, in turn, play a critical role in the development of anti-PRRSV immunity due to their cytotoxic effector functions in clearing infected cells from the body and developing and regulating antigen-specific immune responses [12]. However, whether the peripheral virusspecific immune response is appropriately correlated with the local immune response during infection, which could result in the precise use of the peripheral response as a surrogate for scrutinizing the local immune response during viral clearance, remains unclear. Therefore, discerning the local and peripheral immune responses during PRRSV infection is important for understanding the basic mechanism of viral clearance from the host.

Cytokines secreted by immune cells act on their targets in an autocrine, paracrine, and/or endocrine manner to prompt local and/or systemic immune responses. In porcine respiratory diseases, proinflammatory cytokines play a key role in activating and synchronizing the adaptive immune responses to clear the virus from the body [13]. However, the tissue damage caused by excessive production of these cytokines is controlled by the secretion of anti-inflammatory cytokines, which results in the maintenance of homeostasis in the body [14]. Moreover, effective instigation of the local inflammatory response in the lungs accompanied by significant changes in the proinflammatory cytokine levels in serum has been observed in pigs with respiratory diseases $[15,16]$. Nevertheless, whether the local or the systemic cytokine/ chemokine response plays the primary role in the clearance of PRRSV from pigs during the acute phase of infection remains unclear.

In this context, the present study aimed to investigate the trend of host immune responses against PRRSV infection during disease progression and to elucidate the innate and adaptive immunological mediators modulated by the PRRSV-JA142 strain both systemically in peripheral blood and locally in the bronchoalveolar lavage, lung parenchyma and bronchial lymph nodes (BLN) of infected pigs.

\section{Materials and methods \\ Cells and viruses}

MARC-145 cells, an African green monkey kidney cell line that is highly permissive to PRRSV [17], were used for virus propagation and assays. These cells were maintained in RPMI-1640 medium (Gibco ${ }^{\circledR}$ RPMI-1640, Life Technologies, Carlsbad, CA, USA) supplemented with $10 \%$ heat-inactivated foetal bovine serum (FBS, Life Technologies), $2 \mathrm{mM}$ L-glutamine, and an antibiotic-antimycotic cocktail (Anti-Anti, Life Technologies) containing $100 \mathrm{IU} / \mathrm{mL}$ penicillin, $100 \mu \mathrm{g} / \mathrm{mL}$ streptomycin, and $0.25 \mu \mathrm{g} / \mathrm{mL}$ Fungizone ${ }^{\circledR}$ [amphotericin B] in a humidified chamber with $5 \% \mathrm{CO}_{2}$ at $37{ }^{\circ} \mathrm{C}$. In this 
manuscript, this medium is designated RPMI growth medium. The North American PRRSV-2 strain JA142 (GenBank: AY424271.1) was used in the present study.

\section{Animal study}

One hundred 4-week-old piglets purchased from a PRRSV-seronegative farm were randomly assigned to two groups and housed in separate animal rooms. After 3 days of acclimatization, the pigs in the infected group $(n=75)$ were intramuscularly inoculated with $2 \mathrm{~mL}$ of the PRRSV-JA142 strain $\left(1 \times 10^{3} \mathrm{TCID}_{50} / \mathrm{mL}\right)$ diluted in sterile PBS. The control pigs $(n=25)$ remained uninfected. Feed and water were provided ad libitum to all the pigs. Five pigs from the control group and 12, 16, 14, 18 and 12 pigs from the infected group were humanely euthanized on days $3,10,21,28$ and 35 post-challenge (dpc), respectively. Euthanasia was performed by electrocution after the intramuscular injection of $2 \mathrm{~mL}$ of azaperone $\left(40 \mathrm{mg} / \mathrm{mL}\right.$, StressGuard ${ }^{\circledR}$, Dong Bang Inc., Seoul, South Korea). Three infected pigs died during the course of the experiment due to high fever and reduced body growth. An overview of the animal study is presented in Figure 1. After euthanasia, the lungs, trachea and bronchi were aseptically extracted and lavaged with $75 \mathrm{~mL}$ of sterile PBS. The collected lavage fluid was centrifuged at $1000 \times g$ and room temperature for $10 \mathrm{~min}$ to separate the bronchoalveolar lavage fluid (BALF) and cells (BAL), and these samples, along with the lung parenchyma and BLN, were also used for immune cell analysis. These tissues and BALF were collected in tubes, snap-frozen using liquid nitrogen and stored immediately at $-80{ }^{\circ} \mathrm{C}$ for
RNA extraction and cytokine analysis, respectively. For histopathology, the lung tissues were also collected in $10 \%$ neutral-buffered formalin.

Blood was collected from the euthanized pigs at 3, 10, 21, 28 and $35 \mathrm{dpc}$, and the serum and PBMC were separated. In addition, blood samples from 42 pigs, including uninfected and infected pigs that were going to be euthanized on 28 and $35 \mathrm{dpc}$, were also collected at $0,3,7,10$, 14,21 and $28 \mathrm{dpc}$, and the serum and PBMC were separated. The body weights of all the pigs were measured at $0 \mathrm{dpc}$, and the body weight gains of the euthanized pigs were measured at $3,10,21,28$ and $35 \mathrm{dpc}$.

\section{Quantification of the virus in serum and lung tissue}

Serum viremia was measured at $0,3,7,10,14,21,28$ and $35 \mathrm{dpc}$, and the viral load in the lungs was quantified in the euthanized pigs at 3,10,21, 28 and $35 \mathrm{dpc}$. Viral RNA was extracted from serum using a MagMAX viral RNA isolation kit (Ambion; Applied Biosystems, Life Technologies, Inc.) according to the manufacturer's instructions. Real-time reverse transcription-polymerase chain reaction (RT-qPCR) employing the Prime-Q PCV2 PRRSV Detection Kit (Genet Bio, Daejeon, South Korea) was performed for the quantification of serum viremia. One-step RT-qPCR was performed in accordance with the manufacturer's instructions. PCR amplification was performed using a model 7500 fast real-time PCR system (Applied Biosystems, Foster City, CA, USA). The cycling conditions were as follows: (i) cDNA synthesis for $20 \mathrm{~min}$ at $50{ }^{\circ} \mathrm{C}$; (ii) 10 -min predenaturation step at $95{ }^{\circ} \mathrm{C}$; and (iii) 40 cycles of denaturation for $10 \mathrm{~s}$ at $95^{\circ} \mathrm{C}$

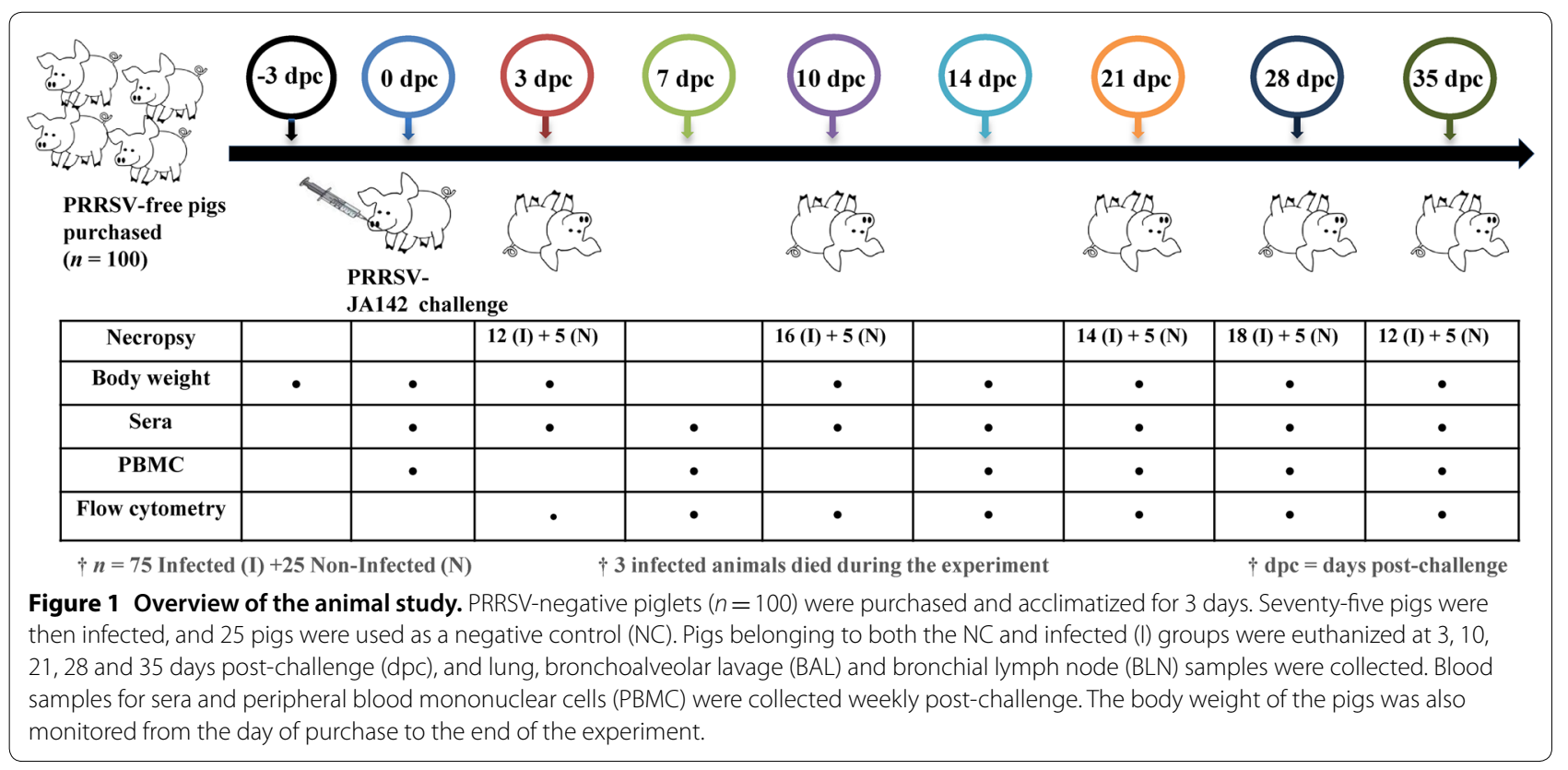


and annealing/extension for $30 \mathrm{~s}$ at $60{ }^{\circ} \mathrm{C}$. To calculate the amount of PRRSV in each sample, the Cq values were converted to virus titres $\left(\mathrm{TCID}_{50} / \mathrm{mL}\right)$ by generating a standard curve through the titration of PRRSV-2 strain JA142.

In addition, MARC-145 cells were used to quantify the virus titres in lung tissues using a microtitration infectivity assay [18]. Briefly, tissue homogenates (10\% [weight/ volume]) of finely chopped lung pieces were prepared in Dulbecco modified Eagle medium (DMEM) with antibiotics, and these mixtures were vortexed vigorously for 10-15 min and then centrifuged at $\sim 4000 \times g$ and $4{ }^{\circ} \mathrm{C}$ for $1 \mathrm{~h}$. The collected supernatant was filtered through a $0.20-\mu \mathrm{m}$ sterile syringe filter and used as an inoculum for the measurement of virus titres. The virus titres were calculated at 5 to 6 days post-inoculation based on the cytopathic effect (CPE) and are expressed as $\mathrm{TCID}_{50} / \mathrm{mL}$ [19].

\section{Pathological evaluation of the lungs}

The lungs of the necropsied pigs in both groups were subjected to pathological evaluation on each day of necropsy. The microscopic lung lesions were given a score on a scale from 0 to 3 to reflect no lesion, mild interstitial pneumonia, moderate multifocal interstitial pneumonia, and severe interstitial pneumonia, respectively. The microscopic lesions were examined from five different lobes of the lungs, and the average value was ultimately utilized for scoring purposes.

\section{Anti-PRRSV-specific antibody detection}

The serum samples from uninfected and challenged pigs were tested for anti-PRRSV antibody (IgG) using a commercially available ELISA kit (PRRS Ab ELISA 4.0; BioNote Inc., Hwaseong-si, Republic of Korea) according to the manufacturer's instructions. Samples with an $\mathrm{S} / \mathrm{P}$ ratio (the ratio of the net optical density of the test samples to the net optical density of the positive controls) $\geq 0.4$ were considered to be positive for the PRRSV antibody.

The serum virus-neutralizing (SVN) antibodies were measured through a fluorescent focus neutralization (FFN)-based SVN assay with MARC-145 cells as described previously [20], with some modifications. After heat inactivation at $56{ }^{\circ} \mathrm{C}$ for $1 \mathrm{~h}$, the serum samples were serially (twofold) diluted using RPMI-1640 growth medium. Two-hundred-microlitre mixtures were prepared by mixing each diluted serum sample with $10^{3}$ fluorescent focus-forming units per $\mathrm{mL}(\mathrm{FFU} / \mathrm{mL})$ of PRRSV-JA142 at a ratio of 1:1 and were then incubated for $1 \mathrm{~h}$ at $37^{\circ} \mathrm{C}$ in a humidified atmosphere with $5 \% \mathrm{CO}_{2}$. Each mixture was transferred onto a monolayer of MARC-145 cells in 96-well plates and incubated for another $1 \mathrm{~h}$ at $37^{\circ} \mathrm{C}$. The medium was replaced with 200 $\mu \mathrm{L}$ of fresh RPMI growth medium per well and further incubated for $20 \mathrm{~h}$ at $37^{\circ} \mathrm{C}$. The cells were later fixed using ice-cold $80 \%(\mathrm{v} / \mathrm{v})$ acetone, air-dried, and stained with mouse anti-PRRS NC Mab 4A5 (Median Diagnostic, Gangwondo, Korea) and FITC-conjugated goat anti-mouse IgG $(\mathrm{h}+\mathrm{l})$ (Bethyl Laboratories, TX, USA). Subsequently, the plates were washed at least three times with PBS and observed under a fluorescence microscope to examine the PRRSV-specific FFU. The SVN titre is expressed as the reciprocal of the highest dilution at which a $90 \%$ or higher reduction in the number of FFU was observed.

\section{Isolation of PBMC, BAL cells, and mononuclear cells from lymph nodes and lung tissues}

PBMC were isolated from the blood samples $(6 \mathrm{~mL})$ by the density gradient method using Leucosep ${ }^{\mathrm{TM}}$ Centrifuge Tubes (Greiner Bio-One North America Inc., NC, USA) and Leucoprep ${ }^{\mathrm{TM}}$ Lymphocyte Separation Media (Greiner Bio-One North America Inc.) according to the manufacturers' instructions. The blood samples were briefly stratified on Leucoprep ${ }^{\mathrm{TM}}$ solution at a ratio of 2:1 (blood:Leucoprep) and centrifuged at $1000 \times g$ for $10 \mathrm{~min}$. The purified PBMC were collected, washed twice with sterile PBS ( $\mathrm{pH} 7.0$ ) and resuspended in $0.5 \mathrm{~mL}$ of sterile PBS supplemented with $1 \%$ heat-inactivated FBS (Gibco, Carlsbad, CA, USA). Contaminating red blood cells $(\mathrm{RBC})$ were removed by treatment with $\mathrm{RBC}$ lysis buffer (eBioscience, CA, USA).

For pathological evaluation, the right-sided lobes were clamped to collect specimens for RNA extraction and histopathology, and the left lobes of the lungs were used for BAL collection according to a previous study [21]. The lungs were lavaged with $50-75 \mathrm{~mL}$ of PBS containing $100 \mu \mathrm{g} / \mathrm{mL}$ ampicillin (USB Corporation Cleveland, OH, USA) and an antibiotic-antimycotic cocktail (Anti-Anti, Life Technologies), and the harvested fluid was centrifuged for $10 \mathrm{~min}$ at $1000 \times g$. The resulting supernatant was collected as BAL fluid (BALF), whereas the cell pellet (BAL cells) was washed three times with PBS after RBC lysis. The cells were resuspended in FACS buffer (3\% FBS in phosphate-buffered saline and $0.02 \%$ sodium azide).

The BLN were passed through a $40-\mu \mathrm{m}$ cell strainer (SPL Life Sciences, Pocheon, Korea) in PBS and then washed with FACS buffer according to a previous study [22]. The single cell suspension obtained was used for flow cytometric analysis.

Mononuclear cells from lung parenchyma were prepared based on a previous study [23], with few modifications. Briefly, lung tissue was collected, washed in sterile ice-cold PBS and suspended in serum-free RPMI media containing DNase I ( $25 \mathrm{U} / \mathrm{mL}$, Sigma, St. Louis, MO, USA) and collagenase D ( $2 \mathrm{mg} / \mathrm{mL}$, Roche Diagnostics, 
Mannheim, Germany). Single-cell suspensions were prepared using the gentleMACS Octo Dissociator (Miltenyi Biotec, San Diego, CA, USA) and incubated at $37^{\circ} \mathrm{C}$ for $30 \mathrm{~min}$. Subsequently, the cells were passed through a 40- $\mu \mathrm{m}$ cell strainer, washed, and resuspended in FACS buffer for flow cytometry analysis after RBC lysis.

Finally, the cells were counted with a Countess ${ }^{\mathrm{TM}}$ Automated Cell Counter (Invitrogen, Carlsbad, CA, USA), and their viability was tested by trypan blue (Sigma-Aldrich, St. Louis, MO, USA) exclusion [24].

\section{Flow cytometry}

For cell surface staining, single-cell suspensions were incubated on ice for $30 \mathrm{~min}$ with specific antibodies as listed in Additional file 1, and the cells were then washed three times with FACS buffer. When necessary, secondary antibodies conjugated with fluorochrome were used. Natural killer (NK) cells, DC and macrophages required only cell surface staining, whereas the different subsets of $T$ cells required intranuclear and intracellular staining.

Two subsets of NK cells have been phenotypically defined based on NKp46 marker expression: NKp46 and NKp46- NK cells $[25,26]$. Following PBMC staining, a similar gating hierarchy was followed by excluding the unstained cells, doublets and $\mathrm{CD}^{+}$cells, and the $\mathrm{CD}^{-}$lymphocytes were further analysed for CD8 $\alpha$ and $\mathrm{NKp} 46$ expression. Among $\mathrm{CD}^{-}$cells, two populations were found in the PBMC, namely, NKp46 $6^{+}$and NKp46 NK cells, and both of these cells were CD8 $\alpha^{+}$(Additional file 2A).

BAL cells were subjected to cell surface staining for the CD163 surface marker, and the viability of these cells was analysed using propidium iodide (PI) staining (Additional file 2B). Additionally, DC and macrophages were segregated from the BAL cell population based on staining and gating strategies outlined previously (Additional file $2 \mathrm{C}$ ) $[10,11]$. From the $\mathrm{MHC}-\mathrm{II}^{+}$cell population, five phenotypically and functionally defined subpopulations were distinguished using the CD163 and CD172a (Sirp $\alpha)$ surface markers. Among the MHC- $\mathrm{II}^{+}$cells, $\mathrm{CD} 172 \mathrm{a}^{+} /$ $\mathrm{CD}_{163} 3^{\text {high }}$ cells were defined as AM, whereas CD172a ${ }^{+}$/ CD163 $3^{\text {int }}, \mathrm{CD}_{172 \mathrm{a}^{+}} / \mathrm{CD} 163^{\text {low }}, \mathrm{CD} 172 \mathrm{a}^{+} / \mathrm{CD} 163^{-}$and

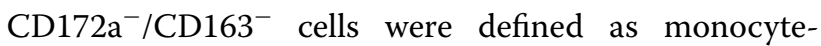
derived macrophages (moM $\phi \mathrm{s})$, monocyte-derived dendritic cells (moDC), conventional dendritic cells 2 (cDC2) and conventional dendritic cells 1 ( $\mathrm{cDC} 1)$, respectively, based on a previous study [10].

Regulatory $\mathrm{T}$ cells (Tregs), which require intranuclear staining of FoxP3 after cell surface staining, were fixed with cold fixation/permeabilization buffer (eBioscience, Thermo Fisher Scientific, Seoul, Korea) at $4{ }^{\circ} \mathrm{C}$ for $30 \mathrm{~min}$ and were then stained for FoxP3 at $4{ }^{\circ} \mathrm{C}$ for $30 \mathrm{~min}$. Based on a previously described staining and gating strategy [27], Tregs $\left(\mathrm{CD} 25^{+} \mathrm{FoxP}^{+}\right.$cells $)$were apparent among the $\mathrm{CD} 4^{+} \mathrm{CD} 8^{-}$population (Additional file 2D).

The T-cell subsets subjected to intracellular staining were stained according to previous studies [28, 29], with few modifications. Briefly, single-cell suspensions were treated with a mixture of $1 \times$ cell stimulation cocktail (eBioscience, Thermo Fisher Scientific, Seoul, Korea) and $1 \times$ brefeldin A (eBioscience, Thermo Fisher Scientific, Seoul, Korea) in RPMI growth media and incubated at $37{ }^{\circ} \mathrm{C}$ in a humidified chamber with $5 \%$ $\mathrm{CO}_{2}$ for $4-5 \mathrm{~h}$. The cells were then stained with antibodies for various cell surface markers in cold FACS buffer for $30 \mathrm{~min}$ at $4{ }^{\circ} \mathrm{C}$, properly washed twice with cold FACS buffer, and fixed with intracellular (IC) fixation buffer (eBioscience, Thermo Fisher Scientific, Seoul, Korea) at $4{ }^{\circ} \mathrm{C}$ for $30 \mathrm{~min}$. For intracellular staining, the cells were washed twice with permeabilization buffer $(200 \mu \mathrm{L} /$ well $)$ and stained with cytokine-specific antibodies in cold permeabilization buffer at $4{ }^{\circ} \mathrm{C}$ for $30 \mathrm{~min}$. Subsequently, the cells were washed twice with permeabilization buffer. The gating strategy employed for obtaining various $\mathrm{T}$-cell phenotypes after the gating of singlet lymphocytes is demonstrated in Additional file $2 \mathrm{E}$.

A $100-\mu \mathrm{L}$ suspension of the stained cell populations in FACS buffer was run on an Accuri C6 flow cytometer (BD Accuri ${ }^{\mathrm{TM}}$ C6 Plus, BD Biosciences, MD, USA). BD Accuri ${ }^{\text {TM }}$ C6 Plus software version 1.0.23.1 (BD Biosciences, MD, USA) was used to analyse the data after setting compensation settings according to monocolour and isotype control stains. The data are presented as percentages of all the cell subsets.

\section{Cytokine immunoassay}

The cytokine levels in the sera and BALF of the uninfected and infected pigs at 3,10 and $28 \mathrm{dpc}$ were measured using a porcine-specific ProcartaPlex ${ }^{\mathrm{TM}}$ Multiplex Immunoassay (ThermoFisher Scientific, Vienna-1030, Austria) according to the manufacturer's instructions. Magnetic microsphere technology based on porcine cytokine/chemokine antibody-immobilized magnetic beads was employed in the immunoassay for cytokine quantification [30]. The concentration of each cytokine was measured by running the samples on the Luminex ${ }^{\circledR}$ $200^{\mathrm{TM}}$ system (Luminex Corporation, Austin, TX, USA). Appropriate standards provided in the kit were utilized to determine the concentration of each cytokine. The machine was verified and calibrated using a Luminex ${ }^{\circledR}$ $100 / 200^{\mathrm{TM}}$ verification kit and a Luminex ${ }^{\circledR} 100 / 200^{\mathrm{TM}}$ calibration kit (Luminex Corporation, Austin, TX, USA) prior to use. 


\section{Data analysis}

Graphical presentations of the data were prepared using GraphPad Prism 7.00 (GraphPad, San Diego, CA, USA), and the data were statistically analysed using SPSS Advanced Statistics 17.0 software (SPSS, Inc., Chicago, IL, USA). A nonparametric T-test (Mann-Whitney U test) was used to compare the viral loads in the lung tissues, the average daily weight gain (ADWG), the phenotypes of various cell subsets and the cytokine responses between two groups. The normalized dead $\mathrm{CD}_{163^{+}}$cells were analysed by repeated ANOVA (Tukey post hoc test) to determine the overall difference, and pairwise comparisons were also performed at different days post-challenge. Spearman rank correlation and linear regression were used to determine the associations between two parameters. Differences were considered statistically significant if $p<0.05$ and are indicated by asterisks and different letters over the bars.

\section{Results}

PRRSV-JA142 infection leads to a reduced growth rate in pigs

The highest viremia and lung viral loads in PRRSV-JA142challenged pigs were detected between 3 and $10 \mathrm{dpc}$ (Figures $2 \mathrm{~A}, \mathrm{~B})$. The mean peak virus titre in serum at $7 \mathrm{dpc}$ was recorded as $10^{4.58} \mathrm{TCID}_{50} / \mathrm{mL}$, whereas the mean peak live viral load in the lungs at $10 \mathrm{dpc}$, which was measured through the microtitration infectivity assay, was $10^{3.34} \mathrm{TCID}_{50} / \mathrm{mL}$. The virus was gradually cleared by $35 \mathrm{dpc}$, at which point, the serum and lung viral loads had decreased to mean values of $10^{0.76}$ and $10^{0.08} \mathrm{TCID}_{50} /$ $\mathrm{mL}$, respectively. As expected, the control group maintained an uninfected state throughout the experiment. The effect of viremia on body weight gain was observed in the infected pigs by calculating the ADWG of the pigs (Figure 2C). The ADWG in the PRRSV-JA142-challenged pigs was significantly lower than that in the control pigs

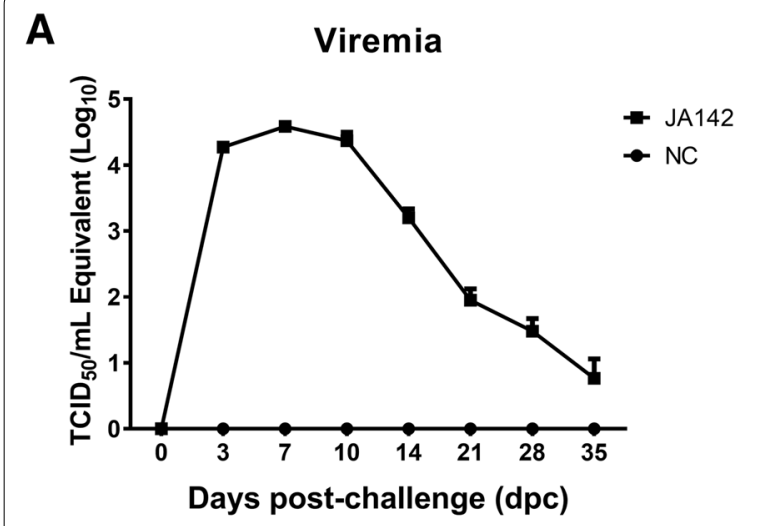

B

\section{Lung viral load}

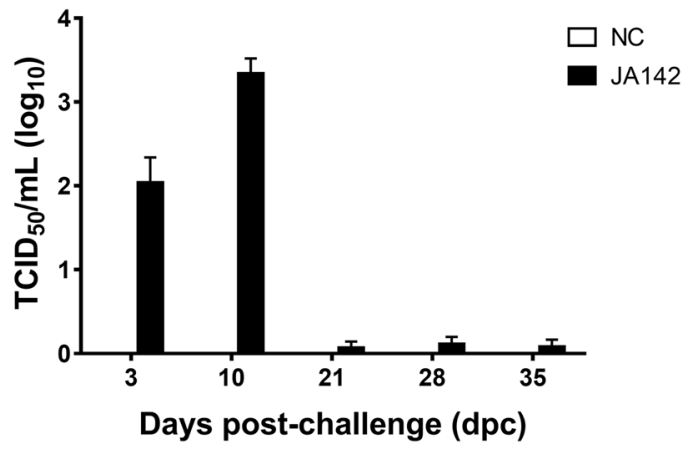

D

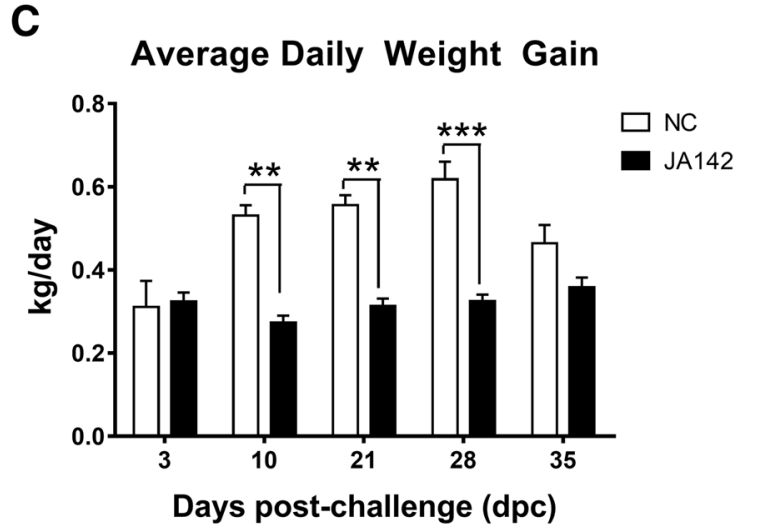

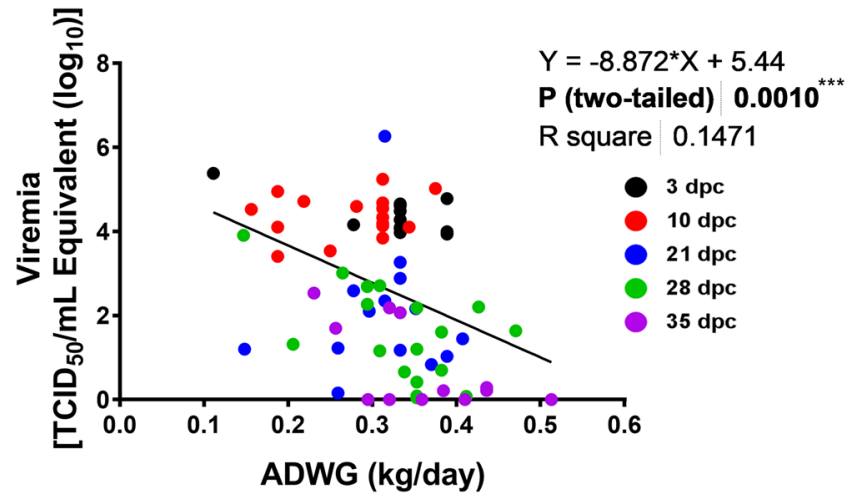

ADWG (kg/day)

Figure 2 Association of PRRSV-JA142 viral loads with the growth rate of pigs. A The viral loads in sera obtained from negative control (NC) and infected (I) pigs at 0,3,7, 10, 14,21, 28 and $28 \mathrm{dpc}$ were quantified by real-time reverse transcription-PCR. The viral titres were calculated based on the standard curve of the threshold cycle number plotted against the known virus titre. B The residual viral lung loads at each necropsy day were quantified using MARC-145 cells based on a microtitration infectivity assay. C The body weight of the euthanized pigs was measured at $-3,3$, 10, 21, 28 and $35 \mathrm{dpc}$, and the average daily weight gain (ADWG) was calculated. D The correlation between viremia and ADWG was tested during the course of infection. The bars represent the means, and the error bars represent the standard errors of the mean (SEM). Bars showing asterisks $\left(^{*}\right)$ represent values that differ significantly from each other ${ }^{* *}$ indicates $p \leq 0.01$ and ${ }^{* * *}$ indicates $\left.p \leq 0.001\right)$. 
at 10, 21 and $28 \mathrm{dpc}$. The ADWG per control pig was recorded as $0.495 \mathrm{~kg}$, whereas the ADWG of the infected pigs was reduced to $0.316 \mathrm{~kg}$. As expected, the growth rate of the pigs was negatively affected by viremia following infection, and this negative correlation was significant $(\mathrm{r}=-0.3809 ; p \leq 0.001)$ (Figure 2D).

\section{Moderate to severe interstitial pneumonia is observed in the infected pigs}

Moderate to severe interstitial pneumonia with alveolar wall thickening due to type 2 pneumocyte proliferation and inflammatory cell infiltration was detected in the infected pigs during the period of peak viremia. Thus, the highest microscopic lung lesion score in the infected pigs was recorded at $10 \mathrm{dpc}$, and the scores of the lung lesions in these pigs decreased at later time points but remained at significantly higher levels compared with those in control pigs (Figures 3A, B).

\section{Kinetics of the anti-PRRSV antibody response}

An ELISA based on the nucleocapsid (N) protein was employed to measure the PRRSV-specific antibody (IgG) response in the infected and noninfected pigs (Figure 4A). At $3 \mathrm{dpc}$, PRRSV-JA142-specific IgG were detected in the serum of the infected pigs. Additionally, the sample-to-positive (SP) value gradually increased in the infected group from 7 to $35 \mathrm{dpc}$, whereas in the control group, the pigs did not produce any PRRSV-specific IgG at any time point. A low SVN titre was observed in the challenged pigs at 28 and $35 \mathrm{dpc}$, when most of the virus was already cleared from the body (Figure 4B). In general, the SVN antibody responses predominantly appear at the later stages of infection, which is the phase at which most of the virus is cleared from the body, and might play a minor role in the clearance of virus.

\section{Early induction of $\mathrm{NKp}^{+} 6^{+}$and $\mathrm{NKp}^{-} 6^{-}$natural killer cells in PBMC post-infection}

NK cells, which are a specialized subpopulation of lymphocytes, are the innate immune cells critically responsible for directly killing virus-infected cells, which ultimately leads to viral clearance in the host [31]. To observe the effect of PRRSV infection on NK cells in pigs, the frequencies of two different NK cell subsets in the PBMC population were analysed. The percentages of $\mathrm{NKp} 46^{-} \mathrm{NK}$ cells $\left(\mathrm{CD}^{+} \mathrm{NKp} 46^{-}\right.$in $\mathrm{CD}^{-}$) in the PBMC populations of the uninfected and infected pigs were higher than those of $\mathrm{NKp} 46^{+}$ $\mathrm{NK}$ cells $\left(\mathrm{CD}^{+} \mathrm{NKp} 46^{+}\right.$in $\left.\mathrm{CD}^{-}\right)$(Additional file $3 \mathrm{~A})$. Moreover, compared with the control pigs, the infected pigs exhibited a significantly $(p \leq 0.05)$ increased frequency of NKp46 ${ }^{+}$NK cells at the early

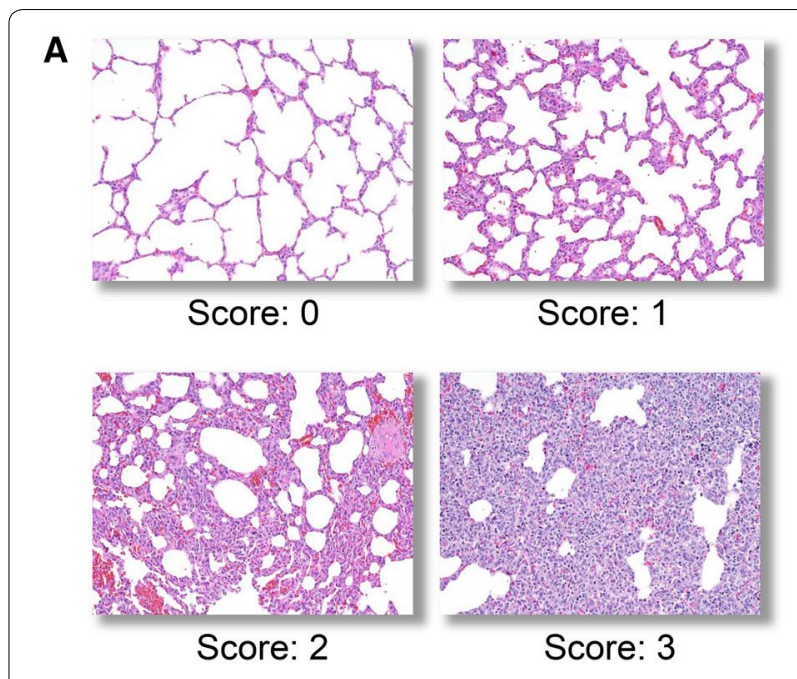

B Microscopic lung lesions

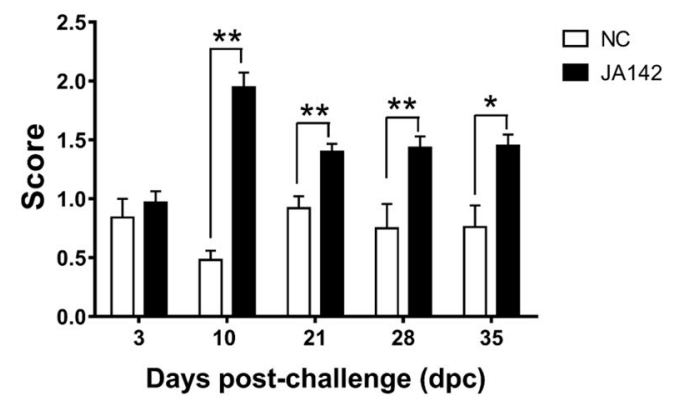

Figure 3 Evaluation of microscopic lung pathology in the pigs on each necropsy day. A Representative slides of H\&E-stained lung sections used for scoring microscopic lesions in the uninfected (NC) and infected (I) pigs based on a 4-point scale from 0 to 3, with 0 representing no lesion, 1 representing mild interstitial pneumonia, 2 representing moderate/multifocal interstitial pneumonia and 3 representing severe interstitial pneumonia. B Mean microscopic lung lesion scores from pigs belonging to both groups on the particular day of necropsy. The error bars represent the SEM, and the bars showing asterisks represent values that differ significantly from each other ( ${ }^{*}$ indicates $p \leq 0.05$ and ${ }^{* *}$ indicates $p \leq 0.01$ ).

time point of $7 \mathrm{dpc}$, whereas the frequency of NKp46NK cells was slightly increased at $7 \mathrm{dpc}$ and significantly increased at $14 \mathrm{dpc}$. The frequency of $\mathrm{NKp} 46^{+}$ NK cells returned to normal values at $21 \mathrm{dpc}$, but the frequency of $\mathrm{NKp} 46^{-} \mathrm{NK}$ cells in the infected pigs remained at significantly higher values up to $28 \mathrm{dpc}$ (Figures 5A, B). The associations between NK cells in PBMC and serum viremia were evaluated post-infection (Figures $5 \mathrm{C}, \mathrm{D}$ ). The $\mathrm{NKp} 46^{+} \mathrm{NK}$ cell population revealed a significant $(\mathrm{r}=0.6621 ; p<0.0001)$ positive correlation with viremia; however, no statistically significant correlation between the levels of NKp $46^{-} \mathrm{NK}$ cells and viremia was observed. 


\section{A Serum ELISA (Anti-PRRSV IgG)}

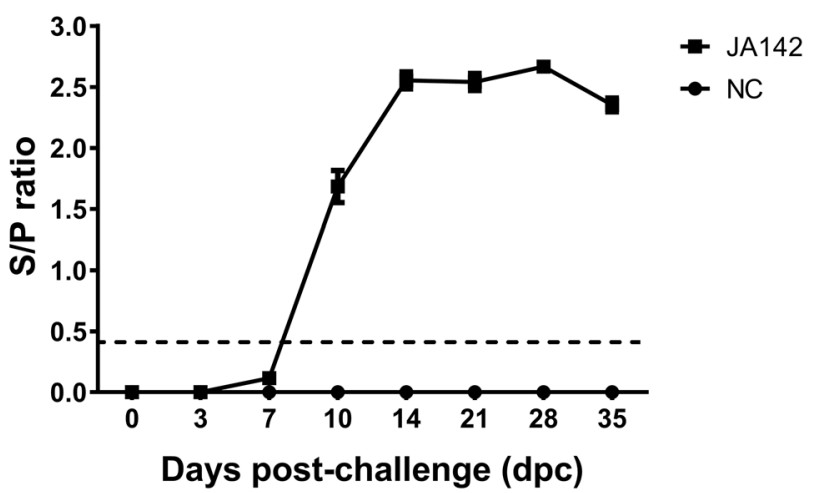

\section{B Serum Virus Neutralization}

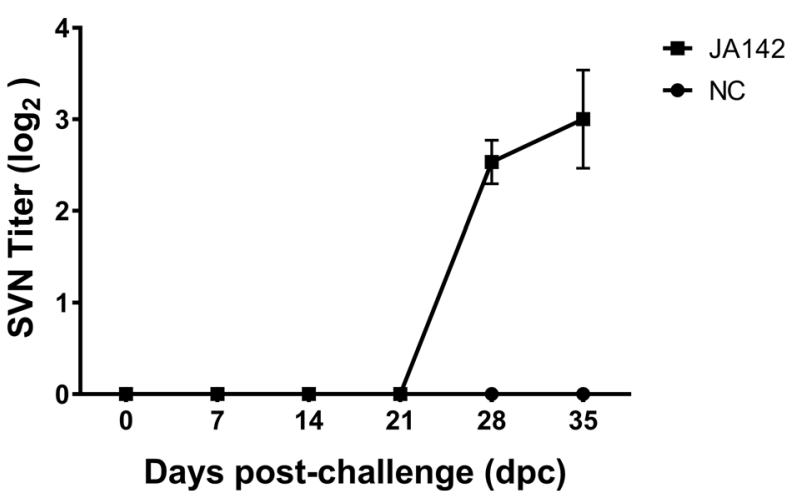

Figure 4 Kinetics of the antibody response in pigs against PRRSV-JA142 infection. A The PRRSV-specific antibody titre in pigs was measured by ELISA. The dashed line indicates the designated threshold value (S/P ratio of 0.4). B Weekly serum virus-neutralizing (SVN) antibody titres in uninfected (NC) and infected pigs obtained using homologous virus as the recall antigen. The bars represent the means, and the error bars represent the standard errors of the mean (SEM).
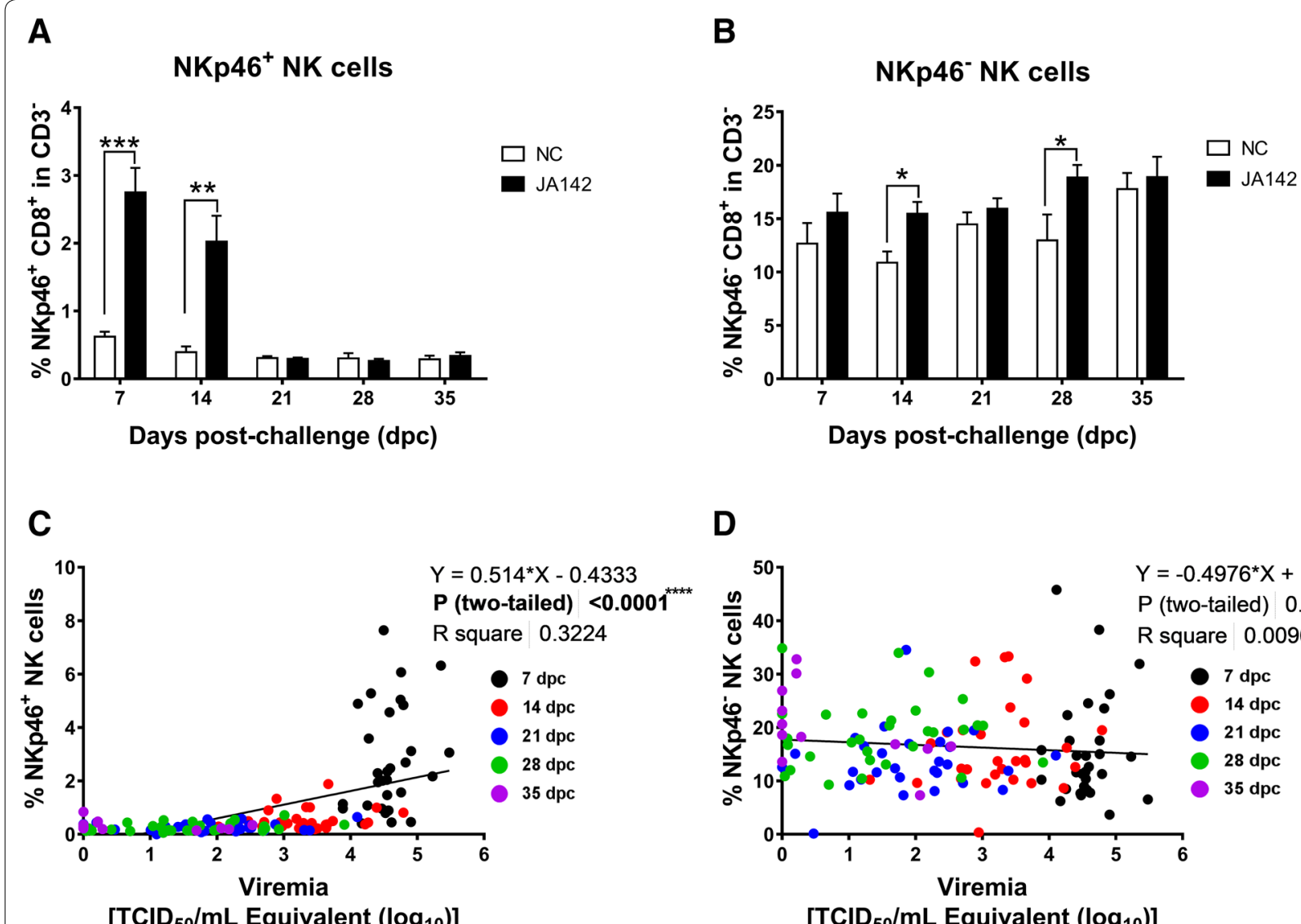

D

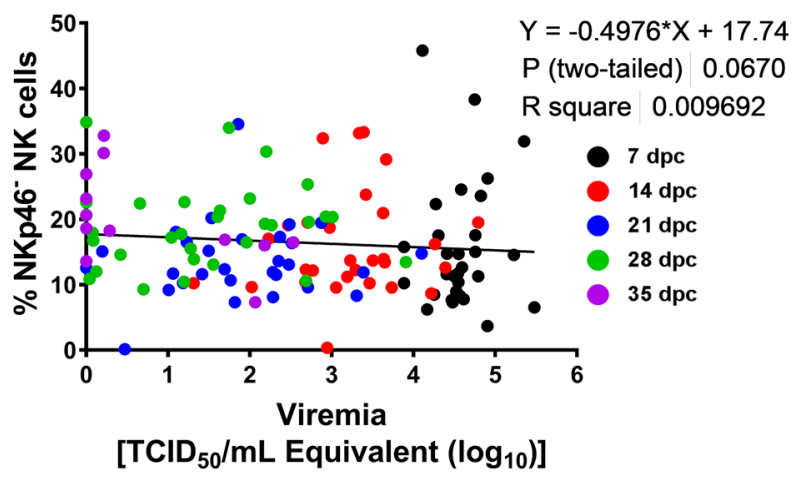

Figure 5 Frequency of NK cells in the PBMC of negative control and infected pigs. A The NKp46 ${ }^{+}$and $\mathbf{B}$ NKp46 ${ }^{-}$NK cell frequency in the PBMC of control (NC) and infected pigs over a period of 35 days post-challenge was tested, and the correlation between viremia and $\mathbf{C}$ NKp46 ${ }^{+}$ and $\mathbf{D}$ NKp46- NK cells was evaluated. An asterisk $\left(^{*}\right)$ over the bar indicates a significant difference $\left({ }^{*}\right.$ indicates $p \leq 0.05,{ }^{* *}$ indicates $p \leq 0.01,{ }^{* * *}$ indicates $p \leq 0.001$ and ${ }^{* * * *}$ indicates $\left.p \leq 0.0001\right)$. 


\section{Dynamics of the respiratory dendritic cell/macrophage network are altered after infection}

The receptors of host cells determine the cell tropism of PRRSV. Among others, CD163, a cysteine-rich scavenger receptor (SRCR), acts as the determinant receptor for PRRSV entry and infection [32,33]. The BAL cells were subjected to CD163 staining, and the results show that although the virus did not affect the CD163 ${ }^{+}$ cells until $3 \mathrm{dpc}$, the infected pigs exhibited a significant $(p \leq 0.05)$ reduction in the $\mathrm{CD} 163^{+}$cell percentage at $10 \mathrm{dpc}$, showing a gradual recovery with the decline in the viral loads at $35 \mathrm{dpc}$ (Figure 6A). The reduction in the $\mathrm{CD}_{163^{+}}$cell population was attributed to the death of $\mathrm{CD}_{163^{+}}$cells, which was confirmed by observing the viability of these cells through PI staining. The mean frequencies of dead $\mathrm{CD} 163^{+}$cells in the infected pigs, which were normalized to those in the uninfected pigs, was significantly $(p \leq 0.05)$ higher at 10 and $21 \mathrm{dpc}$ (32.7\% and $14.35 \%$, respectively) (Figure $6 \mathrm{~B}$ ).

The class II major histocompatibility complex (MHCII) is essential for the presentation of antigens to $\mathrm{T}$ cells and is constitutively expressed on macrophages and DC $[34,35]$. The MHC- $\mathrm{II}^{+}$cells were analysed to observe the changes in the $\mathrm{DC} /$ macrophage network in the lungs. The $\mathrm{MHC}-\mathrm{II}^{+}$cells, such as $\mathrm{CD} 163^{+}$ cells, show significant $(p \leq 0.05)$ decreases at 10 and $21 \mathrm{dpc}$ (Figure 6C). Interestingly, the percentage of AM $\left(\mathrm{CD} 172 \mathrm{a}^{+} / \mathrm{CD} 163^{\text {high }} / \mathrm{MHC}-\mathrm{II}^{+}\right.$cells $)$, which constituted the majority of $\mathrm{MHC}-\mathrm{II}^{+}$cells, decreased significantly at $10 \mathrm{dpc}$ after infection $(p \leq 0.05)$ (Figure $6 \mathrm{D})$. In contrast, the $\mathrm{CD} 172 \mathrm{a}^{+} / \mathrm{CD} 163^{\text {int }} / \mathrm{MHC}$ $\mathrm{II}^{+}$cell $(\mathrm{moM} \phi)$ and $\mathrm{CD} 172 \mathrm{a}^{+} / \mathrm{CD} 163^{\text {low }} / \mathrm{MHC}-\mathrm{II}^{+}$ cell $(\mathrm{moDC})$ frequencies were significantly $(p \leq 0.05)$ reduced in the infected pigs early during the infection process $\left(3 \mathrm{dpc}\right.$ ) (Figures 6E, F). However, the CD172a ${ }^{+} /$ $\mathrm{CD} 163^{\text {int }} / \mathrm{MHC}-\mathrm{II}^{+}$cell percentages in the infected pigs were significantly $(p \leq 0.05)$ increased at 10 and $21 \mathrm{dpc}$, and a higher $(p \leq 0.05) \mathrm{CD} 172 \mathrm{a}^{+} / \mathrm{CD} 163^{\text {low }} / \mathrm{MHC}-\mathrm{II}^{+}$ cell frequency was also detected at 10, 21, 28 and 35 $\mathrm{dpc}$ in the infected pigs compared with the control pigs.

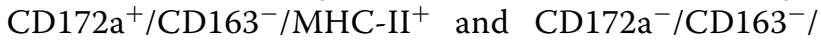

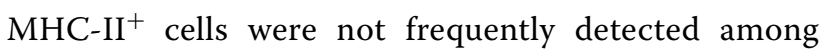
BAL cells and accounted for less than $1 \%$ of the five subsets (Figures 6G, H). At $10 \mathrm{dpc}$, a significantly higher $(p \leq 0.05)$ percentage of these cell populations was observed in the infected pigs, and this value decreased with the reduction in the viral load and the recovery of AM. The associations between the lung viral loads and different subpopulations of macrophages and DC in BAL were evaluated after pooling the results of infected pigs at each time point (Figure 7). During the infection, MHC- $\mathrm{II}^{+}$cells and AM displayed a significant negative correlation $(p<0.05)$ with lung viral loads; however, other subsets exhibited a significant $(p<0.05)$ positive correlation.

During infection, PRRSV-JA142 alters the dynamics of the respiratory $\mathrm{DC} /$ macrophage network by destroying AM while increasing the populations of antigen-presenting cells (APC), which bridge the gap between innate and adaptive immune systems by presenting the foreign antigen to $\mathrm{T}$ cells.

\section{Delayed peripheral T-cell responses in the infected pigs}

The peripheral immune response was measured by analysing the T-cell populations in the PBMC of uninfected and infected pigs at 7, 14, 21, 28 and $35 \mathrm{dpc}$ (Additional file $3 \mathrm{~A})$. The Th1 $\left(\mathrm{IFN}-\gamma^{+}\right.$in $\left.\mathrm{CD} 4^{+} \mathrm{CD}^{-}\right)$response in the infected pigs was significantly higher $(p \leq 0.05)$ than that in the control pigs at $21 \mathrm{dpc}$, and these responses continued to increase until $35 \mathrm{dpc}$. The cytotoxic T lymphocyte (CTL) $\left(\mathrm{IFN}-\gamma^{+}\right.$in $\left.\mathrm{CD} 4^{-} \mathrm{CD} 8^{+}\right)$response in the infected pigs started to increase at $14 \mathrm{dpc}$ and was significantly higher $(p \leq 0.05)$ compared with that in the control pigs at $28 \mathrm{dpc}$ (Figure 8A). At $21 \mathrm{dpc}$, the Th17 (IL17 ${ }^{+}$ in $\mathrm{CD}^{+} \mathrm{CD}^{-}$) cell response was significantly higher $(p \leq 0.05)$ in the infected pigs compared with the control pigs, and the response was further escalated at later time points. The IL-17-producing $\mathrm{CD} 4^{-} \mathrm{CD} 8^{+}$cell population was significantly higher $(p \leq 0.05)$ in the infected pigs compared with uninfected pigs at $21 \mathrm{dpc}$. The delay in the induction of effector $\mathrm{T}$ cells was mainly perceived peripherally in blood.

\section{The local protective T-cell responses coincide with viral clearance}

To observe the activation of the local adaptive immune responses by innate immune cells at the sites of replication and the persistence of PRRSV, the T-cell phenotypes in the BLN, BAL and lung parenchyma of the euthanized control and infected pigs were analysed at 10, 21, 28 and $35 \mathrm{dpc}$. The percentages of various immune cells in the lungs, BAL and BLN of uninfected and PRRSV-JA142infected pigs at different stages of infection are summarized in Additional files $3 \mathrm{~B}, \mathrm{C}$, and D. Overall, various $\mathrm{T}$-cell responses were significantly induced in the lungs as early as $10 \mathrm{dpc}$, and significant responses in BAL and BLN were first detected at $10 \mathrm{dpc}$ and were maintained until $35 \mathrm{dpc}$. The Th1 cell (IFN- $\gamma^{+}$in $\left.\mathrm{CD} 4^{+} \mathrm{CD} 8^{-}\right)$frequency in all the local tissues was significantly $(p \leq 0.05)$ induced in the challenged pigs as early as $10 \mathrm{dpc}$, and the frequency in BAL cells tended to be higher. The CTL $\left(\mathrm{IFN}-\gamma{ }^{+}\right.$in $\left.\mathrm{CD} 4^{-} \mathrm{CD} 8^{+}\right)$frequency was significantly $(p \leq 0.05)$ higher in the lungs of the infected pigs compared with that of the control pigs at $10 \mathrm{dpc}$, whereas the frequency in BLN and BAL cells was higher at the early time point and significantly higher at $21 \mathrm{dpc}$. The 
A

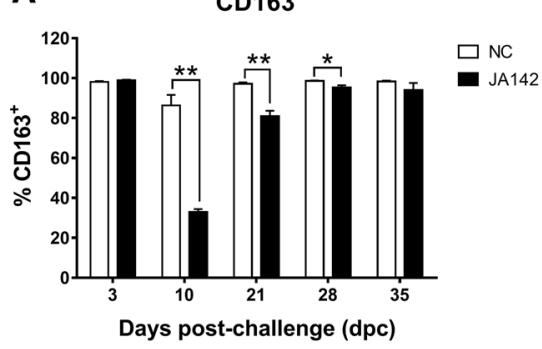

C

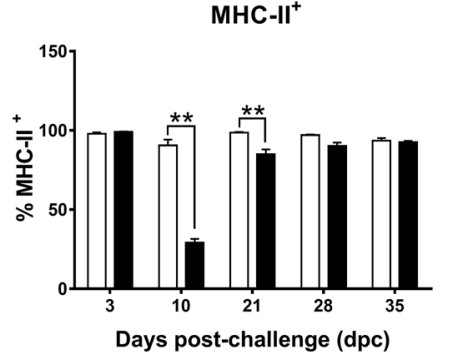

E

CD172a $\mathrm{a}^{+} / \mathrm{CD} 163^{\mathrm{int} / \mathrm{MHC}-\mathrm{II}^{+}}$

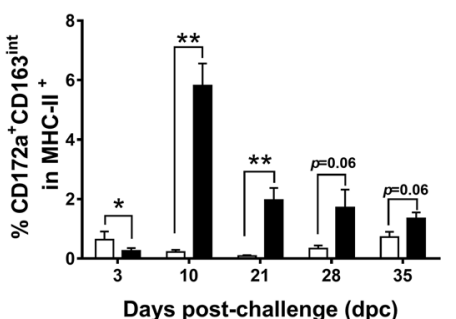

G

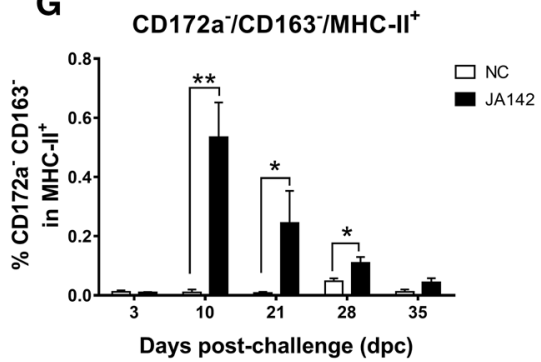

B

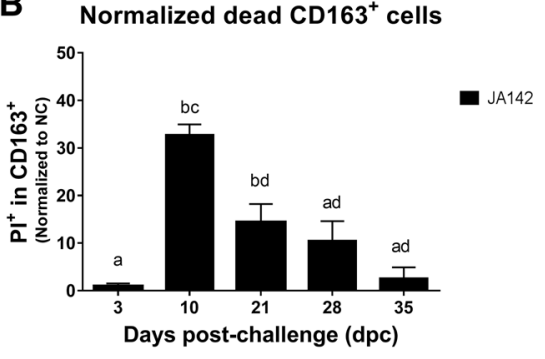

D

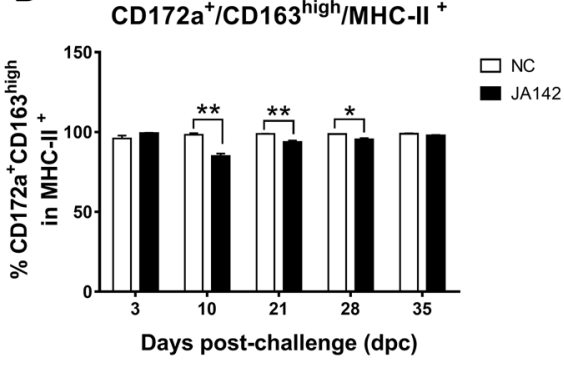

$\mathbf{F}$

CD172a ${ }^{+} / C D 163^{\text {low } / M H C-1 I^{+}}$

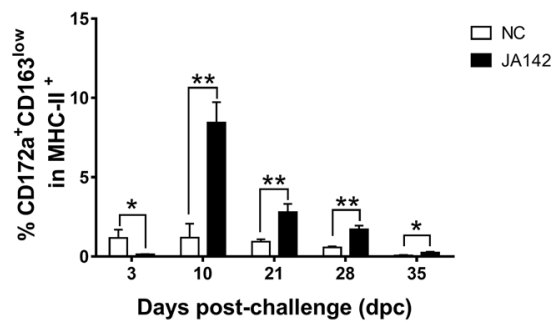

H CD172a $\mathrm{a}^{+} / \mathrm{CD} 163 / \mathrm{MHC}-\mathrm{II}^{+}$

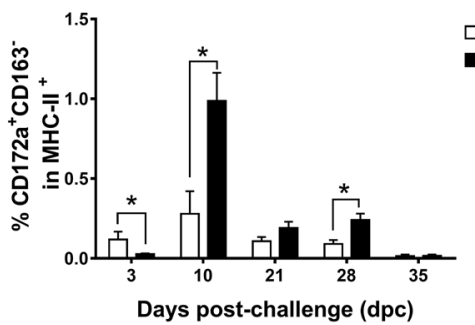

Figure 6 Fluctuations in the frequencies of lung macrophage and dendritic cell phenotypes during infection. Single-cell suspensions of BAL samples obtained from the right diaphragmatic and cardiac lobes of uninfected (NC) and infected pigs were stained for multicolour flow cytometry to detect fluctuations in the $\mathbf{A}$ total $\mathrm{CD} 163^{+}$cell population and the $\mathbf{B}$ normalized dead $\mathrm{CD} 163^{+}$cells at each necropsy day. The dynamics of the respiratory macrophage/DC network were observed by flow cytometric analysis of the BAL cells. C MHC- $\|^{+}$cells were identified and further divided into five subsets based on the expression of CD163 and CD172a. Two subsets fitted to the macrophage lineage and were recognized as D CD172a ${ }^{+} /$CD $163^{\text {high }} / \mathrm{MHC}-I^{+}$(alveolar macrophages; AM) and E CD172a ${ }^{+} /$CD 163 $3^{\text {int } / M H C-1 I^{+}}$(monocyte-derived macrophages; moM $\phi$ ), whereas the remaining three subsets were classified as dendritic cells and were identified as $\mathbf{F}$ CD172a ${ }^{+} / \mathrm{CD} 163^{\text {low }} / \mathrm{MHC} \mathrm{II}^{+}$ (monocyte-derived dendritic cells; moDCs), G CD172a ${ }^{-} / \mathrm{CD} 163^{-} / \mathrm{MHC}-\|^{+}$, and $\mathbf{H} \mathrm{CD} 172 \mathrm{a}^{+} / \mathrm{CD} 163^{-} / \mathrm{MHC}-\mathrm{II}^{+}$. The bars represent the means, and the error bars represent the standard errors of the mean (SEM). Bars showing asterisks and different letters represent values that differ significantly from each other ( ${ }^{*}$ indicates $p \leq 0.05,{ }^{* *}$ indicates $p \leq 0.01$ and ${ }^{* *}$ indicates $p \leq 0.001$ ). 

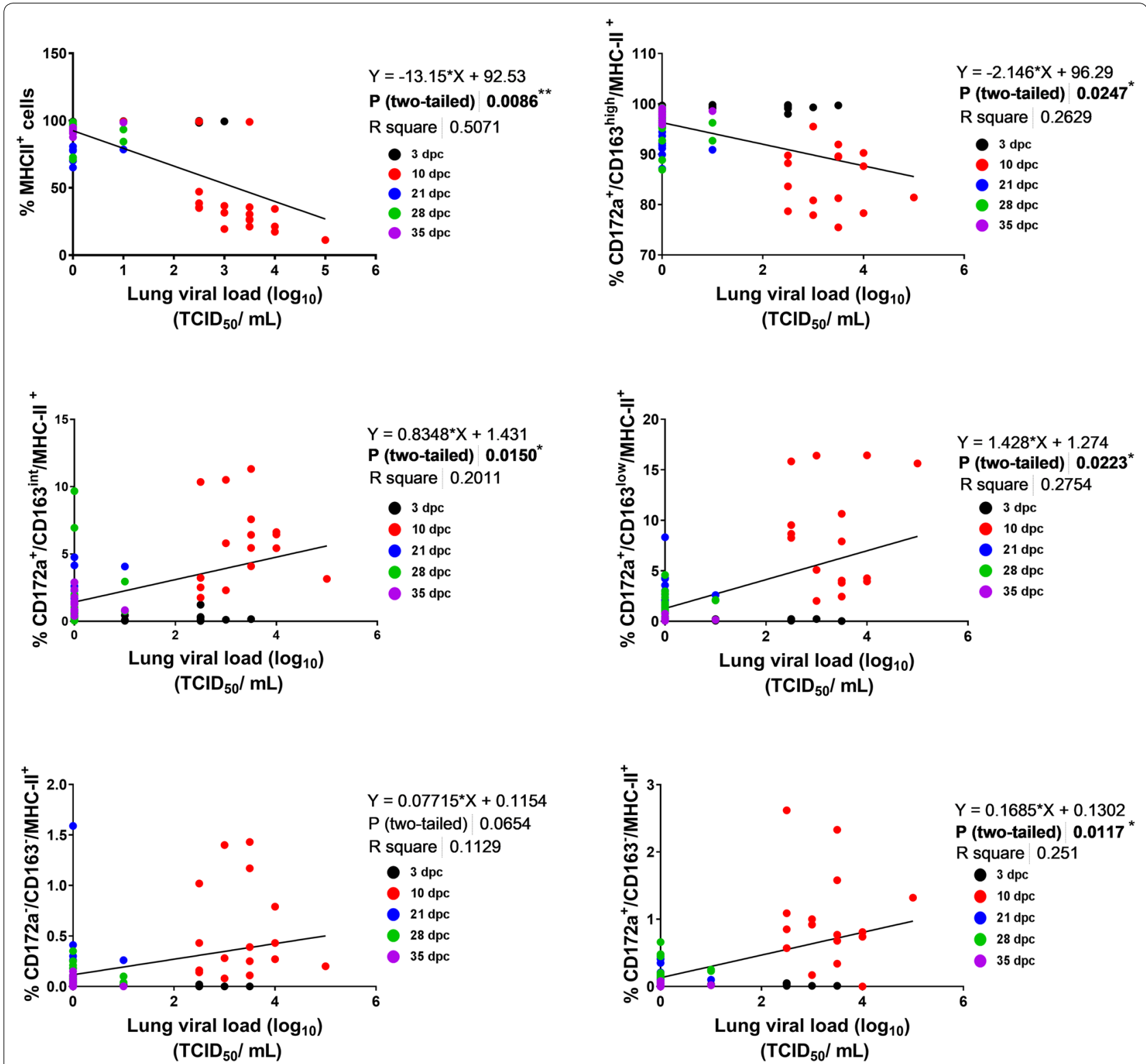

Figure 7 Association between lung macrophage/dendritic cell phenotypes and lung viral loads in pigs after infection. The correlation between different subsets of the DC/macrophage network in BAL cells and the lung viral loads was tested (* indicates $p \leq 0.05$ and ${ }^{* *}$ indicates $p \leq 0.01)$

PRRSV-JA142-infected pigs also displayed a higher induction $(p \leq 0.05)$ of Th17 cells $\left(\mathrm{IL}_{1} 7^{+}\right.$in $\left.\mathrm{CD} 4^{+} \mathrm{CD} 8^{-}\right)$ in the lymph nodes and lung tissues at $10 \mathrm{dpc}$, whereas a slight increase in these cells was observed in BAL cells. The IL-17-producing $\mathrm{CD} 4^{-} \mathrm{CD} 8^{+}$population was significantly $(p \leq 0.05)$ induced in the lungs and BAL cells of the infected pigs at $10 \mathrm{dpc}$, whereas in BLN, this cell population showed a slight increase at $10 \mathrm{dpc}$ and a significant increase $(p \leq 0.05)$ at $21 \mathrm{dpc}$ (Figures 8B-D). Therefore, compared with the weak and delayed peripheral responses, early and effective cellular immune responses were triggered in local tissues by PRRSV-JA142 infection.

\section{PRRSV-JA142 does not induce regulatory T cells in infected pigs}

Tregs are well known for their immunosuppressive activities, and previous studies have demonstrated that PRRSV infection induces Treg responses that might be responsible for ineffective adaptive immune responses [36-38]. Unlike previous studies, no upregulation of 


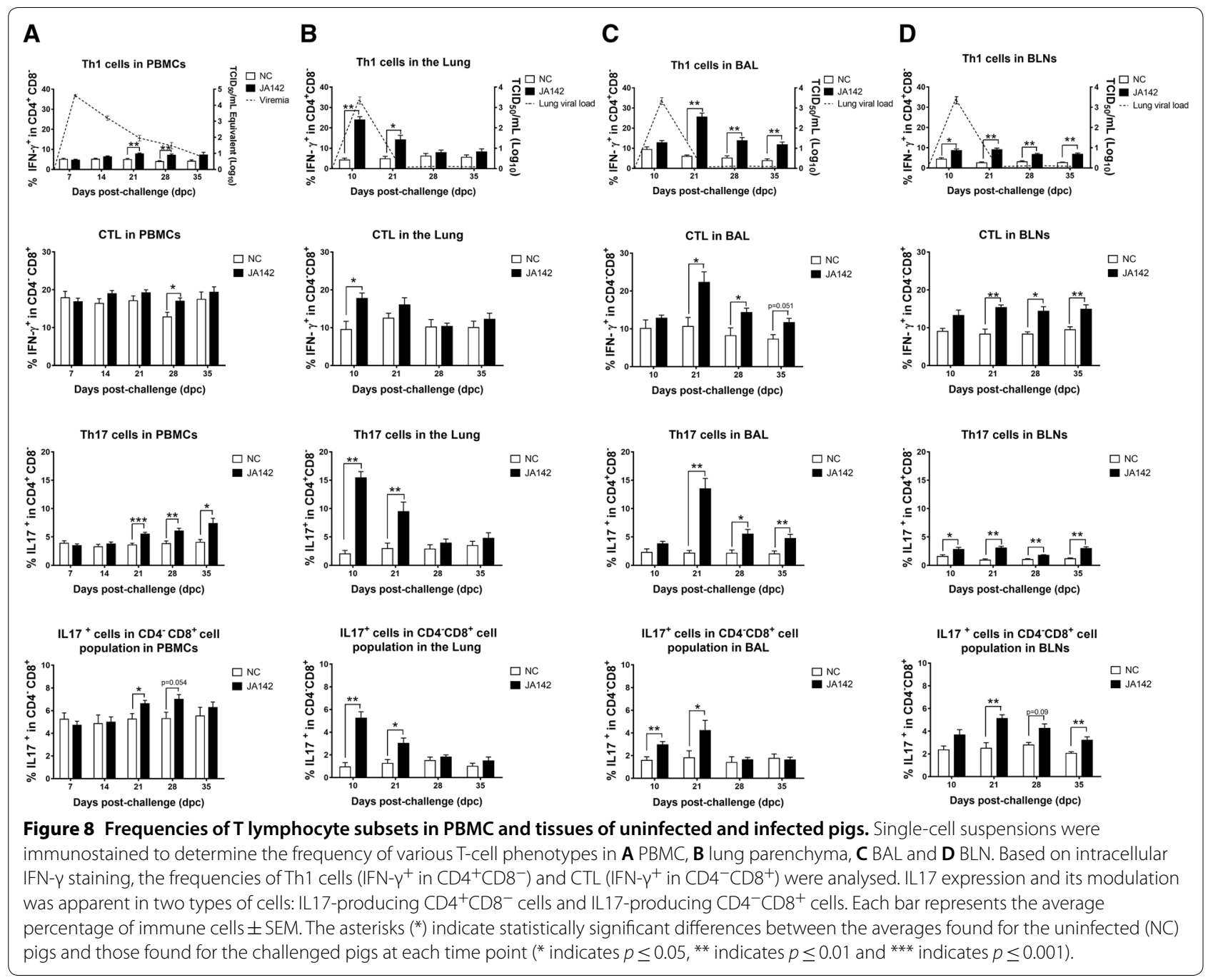

Tregs $\left(\mathrm{CD} 25^{+} \mathrm{Foxp}^{+}\right.$in $\left.\mathrm{CD} 4^{+} \mathrm{CD} 8^{-}\right)$was detected in PBMC isolated from PRRSV-infected pigs. Moreover, Tregs were significantly $(p \leq 0.05)$ reduced in the BAL throughout the course of infection, but no such decline was observed in the lungs (Figure 9). However, the Treg frequencies in BLN of the infected pigs initially exhibited a significant decline at $10 \mathrm{dpc}$ but then increased significantly at $21 \mathrm{dpc}$.

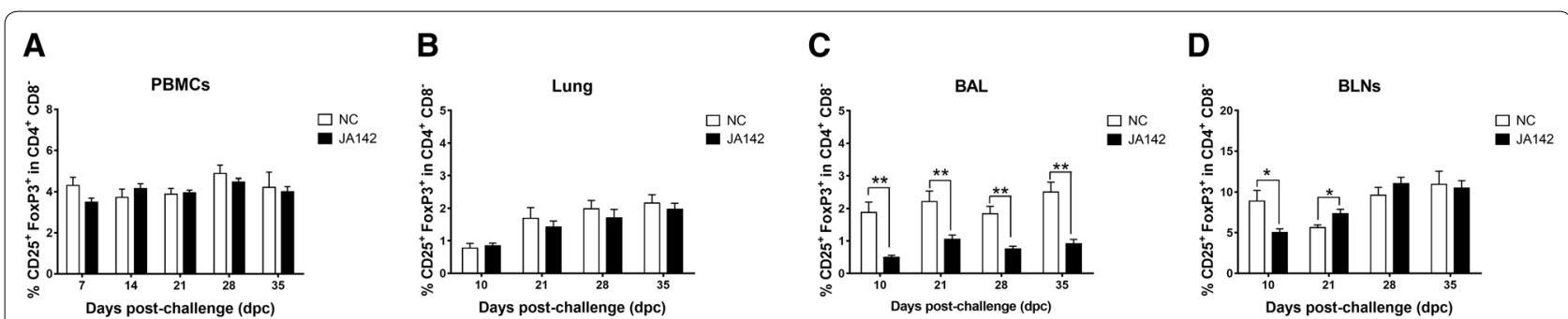

Figure 9 Frequencies of regulatory T-cell populations. The percentages of $\mathrm{CD} 25^{+} \mathrm{Foxp} 3^{+}$cells in the $\mathrm{CD} 4^{+} \mathrm{CD} 8^{-} \mathrm{T}$ lymphocyte populations in PBMC, BLN, BAL and lung parenchyma single-cell suspensions were enumerated by flow cytometry. The frequency of the Treg subpopulations in the negative control and infected pigs at each time point during the course of infection is presented in the graphs. The data represent the mean \pm SEM for each population, and the asterisk $\left(^{*}\right)$ indicates a statistically significant difference between the averages found for the negative control (NC) pigs and those obtained for the challenged pigs at each time point (* indicates $p \leq 0.05$ and ** indicates $p \leq 0.01$ ). 


\section{The localized induction of proinflammatory cytokine} responses was pragmatic at peak viremia

The levels of seven different innate and adaptive cytokine/chemokine proteins in the sera and BALF at 3,10 and $28 \mathrm{dpc}$ were compared between the uninfected and infected pigs (Figure 10). The results reveal that interferon- $\alpha$ (IFN- $\alpha)$ was significantly $(p \leq 0.05)$ induced in the sera and BALF of the infected pigs at 3 dpc. However, at peak viremia $(10 \mathrm{dpc})$, the IFN- $\alpha$ level was reduced peripherally in the sera of the infected pigs, whereas the cytokine level was elevated locally in the BALF. Nevertheless, significant increases in the level of this cytokine $(p \leq 0.05)$ were maintained both locally and systemically in the infected pigs compared with the uninfected pigs. Furthermore, proinflammatory cytokines/chemokines, such as tumour necrosis factor- $\alpha$ (TNF- $\alpha$ ), interleukin-1 $\beta$ (IL-1 $\beta)$, IL- 6 , IL- 8 and
IL-12, show a similar pattern of early induction at $3 \mathrm{dpc}$ in the sera of the infected pigs followed by decreases as viremia increased. In the sera, significant $(p \leq 0.05)$ changes in IL- $1 \beta$ were only observed in the infected pigs at 3 and $28 \mathrm{dpc}$. However, significant $(p \leq 0.05)$ induction of IL-1 $\beta$ and IL- 6 locally in the BALF was observed in the infected pigs at $3 \mathrm{dpc}$. In addition, elevations in all the proinflammatory cytokine/chemokine levels were observed in the infected pigs as the viral load increased, and significant increases in the levels of IL-1 $\beta$, IL- 6 , IL- 8 and IL-12 were observed in the infected pigs compared with the uninfected pigs at 10 dpc. Moreover, IL-10, an anti-inflammatory cytokine, was significantly induced $(p \leq 0.05)$ at 3 and $10 \mathrm{dpc}$ in the BALF of the infected pigs. Overall, the clearance of the virus from the pigs also coincided with the increased secretion of anti-viral and proinflammatory

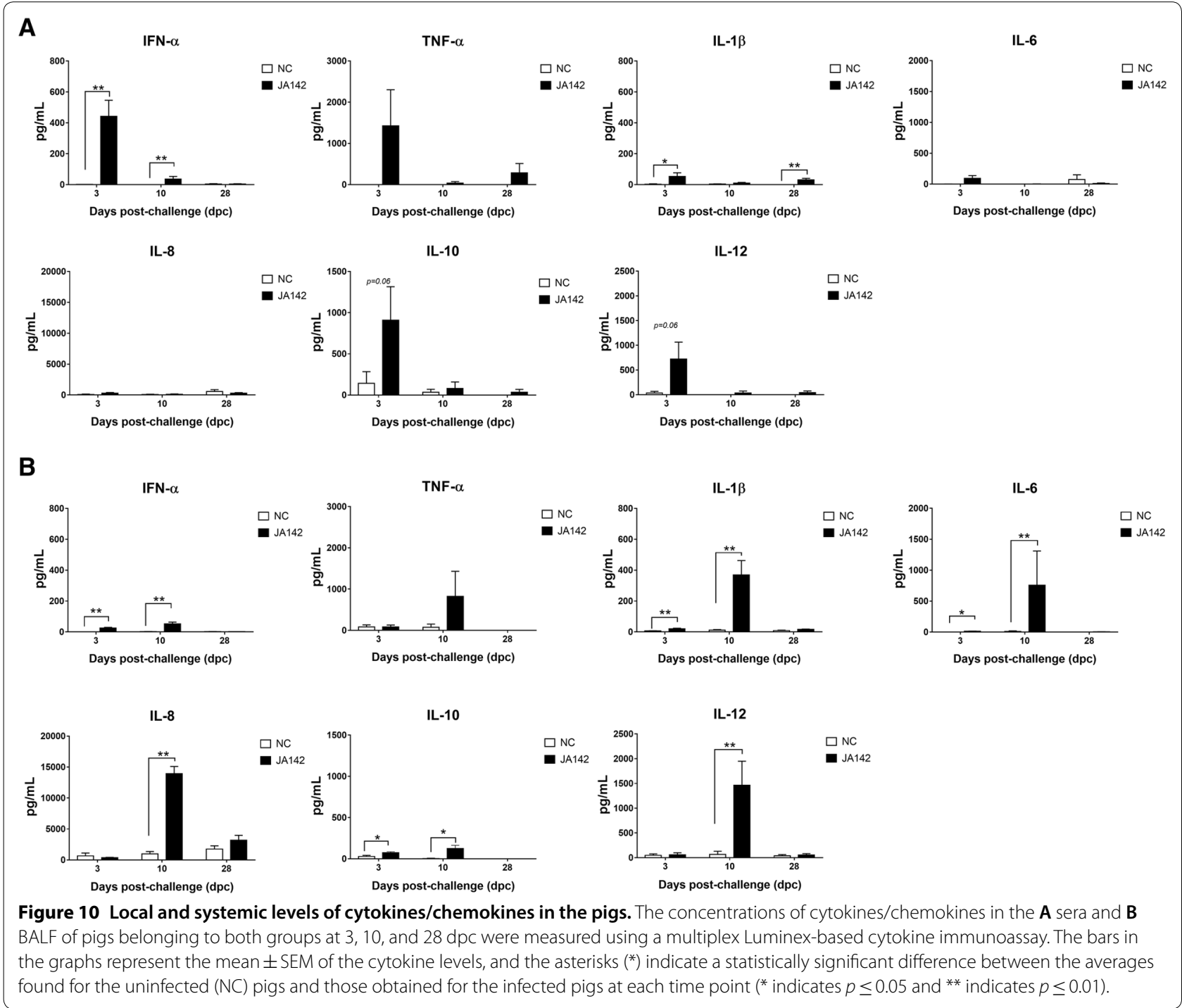


cytokines locally in the BALF of PRRSV-infected pigs, although no considerable shifts were detected in the serum.

\section{Discussion}

Despite exhaustive research, the understanding of the protective immune responses against PRRSV in pigs remains limited. Previous studies have mainly focused on certain aspects of immune responses and/or have used a narrow time window to study the immune responses during PRRSV infection; therefore, the available data offer a limited picture of the host defence system. To the best of our knowledge, the present study constitutes the first investigation of various aspects of immune responses, such as local vs. systemic and innate $v s$ adaptive, during the course of PRRSV infection to obtain a broader picture of the host defence against PRRSV. Here, we demonstrate the critical role of local immune responses in the clearance of PRRSV from pigs due to the early induction of $\mathrm{DC} /$ macrophage subsets, the activation of protective $\mathrm{T}$ cells in local lymphoid and lung tissues, and the stimulation of proinflammatory cytokines locally in the lungs.

In pigs that were intramuscularly inoculated with the biologically characterized PRRSV-JA142 strain [20], the viral titre reached its peak value in the serum and lungs between 3 and $10 \mathrm{dpc}$. In addition, moderate to severe interstitial pneumonia and a significant decrease in the ADWG, which are characteristics of PRRSV infection [39], were detected in the challenged pigs by $10 \mathrm{dpc}$. Mild histopathological lesions (with a lesion score lower than 1) characterized by alveolar wall thickening due to type 2 pneumocyte proliferation were also observed in some of the uninfected healthy pigs that were free of other respiratory pathogens. These observations were likely obtained due to the stress induced by environmental factors, such as housing conditions, weaning, individual space, and ambient temperature variations, as previously reported [40, 41].

Similar to previous reports [7], the PRRSV-JA142 strain induced delayed $(\geq 28 \mathrm{dpc})$ and weak $(\leq 8) \mathrm{SVN}$ titres in infected pigs. An SVN antibody titre of 32 offers sterilizing immunity, whereas a titre greater than 8 is considered protective against PRRSV infection [42]. The anti-PRRSV antibody response induced by PRRSV-JA142 in the infected pigs crossed the threshold of $0.4(\mathrm{~S} / \mathrm{P}$ ratio) between 3 and $10 \mathrm{dpc}$, and this response was in accordance with the response produced by other PRRSV strains [5], but the role of these antibodies in protection against PRRSV infection is unknown [12].

NK cells, an important component of the innate host defence system, play a critical role in the resolution of viral infections [31]. In general, the potential roles of NK cells in relation to PRRSV immunity are poorly understood [43, 44]. In the current study, two defined NK cell subpopulations were distinguished in PBMC based on an approach similar to one previously described [25]. Similar to previous observations, the $\mathrm{NKp} 46^{+} \mathrm{NK}$ cell frequency in PBMC collected from both control and infected pigs was lower than that of $\mathrm{NKp}^{-} 6^{-}$cells. $\mathrm{NKp} 46^{+}$and the NKp46- NK cells execute analogous cytolytic activities but produce different levels of IFN$\gamma$, with $\mathrm{NKp} 46^{+} \mathrm{NK}$ cells producing higher amounts of IFN- $\gamma$. Moreover, NKp46 can be expressed in NKp46NK cells after stimulation with interleukins (IL)-2, IL-12 and IL-18 [25]. In the current study, early increases in the frequencies of NKp46 $6^{+}$and NKp46- NK cells in PRRSV-JA142-challenged pigs were clearly detected. Previous studies have shown similar increases in the $\mathrm{CD}^{-}{ }^{-} \mathrm{CD} 4^{-} \mathrm{CD} 8^{+}$cell population after infection with different strains of PRRSV $[7,45]$. Induced proliferation of NK cells has also been perceived after influenza infection, suggesting that this subset of lymphocytes is capable of antigen-specific clonal expansion [46]. PRRSV, however, significantly suppresses NK cell-mediated cytotoxicity to evade the host immune response [45], but these previous studies did not consider the subsets of NK cells. The specific action of different subsets of NK cells on PRRSV has not yet been explored, and further studies are needed to explain the role of NK cells in the containment of the virus during infection.

The main targets of PRRSV are cells belonging to the monocyte and macrophage lineages, particularly AM. However, DC are also reportedly vulnerable to PRRSV infection [47]. The DC/macrophage network, which senses the foreign antigen and initiates the immune response, constitutes one of the main components of the respiratory immune system [10]. It is plausible to expect that the viral infection of these cells alters this network and thus affects downstream immune responses. Therefore, dissecting how these immune cells respond to PRRSV infection is important to better understand the nature of PRRS. Until now, limited studies have investigated the alterations in the respiratory $\mathrm{DC} /$ macrophage network in pigs during disease progression $[8,10]$, and the association of the alteration in this immune network with the T-cell response has not been reported. Here, we attempted to explore the dynamics of this important host defence mechanism in relation to PRRSV infection. During infection, PRRSV replicates in the $\mathrm{CD}_{16} 3^{+}$cells in the lungs and induces apoptosis at the early stages of infection [33]. In the current study, a flow cytometric analysis of BAL cells revealed that PRRSV-JA142 decreased the $\mathrm{CD}_{163}{ }^{+}$cell population in the infected pigs at the time when peak viral loads were detected. After the viral load decreased, the $\mathrm{CD}_{163^{+}}$cell population recovered to the normal levels. PI staining of the $\mathrm{CD}_{163^{+}}$BAL cells 
revealed that the decrease in the $\mathrm{CD} 163^{+}$cell population was due to cell death. A similar reduction in the macrophage population after PRRSV-1 infection was previously reported [48]. Following the strategy described previously [11], different subsets of DC and macrophages were identified in BAL cells, and the changes in the populations of these subsets during disease progression were studied. Previous reports verify that PRRSV infection impairs DC function directly by downregulating MHCII expression [24, 49]. Intriguingly, among the five cell subsets in $\mathrm{MHC}-\mathrm{II}^{+}$cells, only the $\mathrm{CD} 172 \mathrm{a}^{+} / \mathrm{CD} 163^{\text {high }} /$

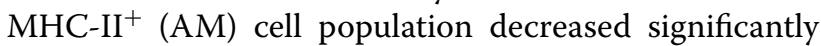
at peak viremia, revealing a significant negative correlation between the population of these cells and the viral loads in the lungs, whereas significant positive correlations were found for the other subset populations. The increases in the $\mathrm{CD} 172 \mathrm{a}^{+} / \mathrm{CD} 163^{\text {int }} / \mathrm{MHC}-\mathrm{II}^{+}$and $\mathrm{CD} 172 \mathrm{a}^{+} / \mathrm{CD} 163^{\text {low }} / \mathrm{MHC}-\mathrm{II}^{+}$cell populations can be attributed to the higher influx of monocytes and their differentiation in the lungs during inflammation. Moreover, $\mathrm{CD} 172 \mathrm{a}^{+} / \mathrm{CD}_{163}{ }^{-} / \mathrm{MHC}^{-\mathrm{II}^{+}}$and $\mathrm{CD}^{-} 172 \mathrm{a}^{-} / \mathrm{CD} 163^{-} /$ MHC-II ${ }^{+}$cells exhibit strong migration and antigenpresenting capabilities [10], which can be credited to the increased influx of these cells into the lungs during the course of infection. Our results were in agreement with those obtained in previous studies, which found that the populations of these cells are increased in the BAL after PRRSV-1 infection [8]. Interestingly, $\mathrm{cDC} 1 \mathrm{~s}$ activate allogenic naïve $\mathrm{T}$ cells and aid induction of the Th1 response, whereas cDC2s induce a Th2 response in pigs [10]. After sensing antigen, the mature migrating DC recruit NK cells to drain LN, thus providing an early source of IFN- $\gamma$ and thereby promoting Th1 polarization [50]. Thus, DC work together with NK cells to regulate innate immunity and further dictate the direction and intensity of the adaptive immune response [51].

The effective immune response to counter viral infections is governed by the proper activation of $\mathrm{T}$ lymphocytes by APC [52]. In the current study, we analysed the dynamics of $\mathrm{T}$ lymphocytes in PBMC, lung parenchyma, BAL, and BLN to detect the central cause of the clearance of PRRSV from the body. Delayed induction of Th1, Th17 and CTL responses was observed in the PBMC of the infected pigs after $21 \mathrm{dpc}$, when most of the virus had been cleared from the blood, whereas in BLN, the virus persists for a longer period, which leads to early and sustained ( $>35 \mathrm{dpc}$ ) induction of $\mathrm{T}$ cell responses. Previous studies also found a delayed induction of effector T cells in the peripheral blood of pigs infected with PRRSV [7, 29]. Intriguingly, significant increases in the frequencies of these $\mathrm{T}$ lymphocyte subpopulations were detected in the lung parenchyma and lymphoid tissues of the infected pigs at early stages of infection $(10 \mathrm{dpc})$, when the virus levels were at their peak in the body. In agreement with our findings, a higher frequency of T-helper cells and CTL has been observed in local tissues, such as the BAL, lymph nodes and lung parenchyma, of pigs after swine influenza infection, and this induction has been linked to viral clearance [23]. The local cell-mediated immune responses are considered crucial for the clearance of the influenza virus [53]. Moreover, during human respiratory syncytial virus infection, increased populations of $\mathrm{CD}^{+}$and $\mathrm{CD} 8^{+} \mathrm{T}$ cells exhibiting effector functions have been observed in the BAL of infected patients [54]. A recent study investigating T-cell proliferation in PRRSV-2-infected PBMC at $28 \mathrm{dpi}$ and the expression of lymph node-homing receptors revealed that the T-helper cell response plays a main role in viral clearance and that the CTL response is strongest at the site of infection [55]. In addition, the induction of Th17 cells in local tissues has also been found to be essential for the resolution of respiratory infections [56]. In the present study, the cell responses in BLN and BAL were found to be significantly increased from 10 or $21 \mathrm{dpc}$ and were maintained until $35 \mathrm{dpc}$, when the virus was completely cleared. Therefore, it can be concluded that local T-cell responses in the lungs, BLN and BAL are induced markedly faster than systemic responses and are maintained at significantly high levels, even after virus clearance, substantiating the critical role of local immune responses in the clearance of PRRSV from pigs.

The Treg lineage is responsible for the maintenance of homeostasis in the immune system by suppressing the activation of various immune cells, including other $\mathrm{T}$ cells, NK cells and DC [57]. Treg play a vital role in the pathogenesis of some viral infections that result in severe inflammatory lesions, such as influenza [23]. However, the Treg response in pigs after PRRSV infection is controversial. Although some studies have revealed increased frequencies of Tregs after PRRSV infection [36, 37, 58], other studies revealed that the induction of Tregs was not changed and even suppressed after infection [7, 27]. These conflicting results could be due to the strainspecific response of the pigs to the virus after challenge or to the method used to evaluate the changes in the Treg response. Several studies have revealed that Tregs are induced due to PRRSV infection, but most of these studies were performed using in vitro or ex vivo assays in which PBMC and mononuclear cells isolated from the lungs and lymph nodes of pigs were infected or reinfected with PRRSV and subsequently observed to monitor the proliferation of various T-cell subsets $[36,37,58]$. However, some ex vivo assays have also demonstrated the inability of certain strains of PRRSV to induce Tregs [59]. In the current study, the Treg frequencies were directly evaluated in the peripheral blood, BAL, lung and 
lymphoid tissues collected from PRRSV-JA142-infected pigs. During the acute phase of infection, the Treg frequencies largely remained unchanged, but suppression was observed in the BAL throughout the infection period and in BLN at $10 \mathrm{dpc}$. Comparable results were obtained in a previous in vivo study, revealing that the Treg numbers remained unchanged in the PBMC, lymph nodes and tonsils of the infected pigs up to $28 \mathrm{dpc}$ [7]. Similar results were observed in another study, which showed no significant upregulation of Tregs in the lymph nodes and PBMC at the acute phase of PRRSV infection [27]. Furthermore, the decrease in Treg frequencies in JA142infected pigs could be attributed to phenotypic plasticity, which resulted in most of the naive $\mathrm{CD} 4^{+} \mathrm{T}$ cells differentiating into effector cells, such as Th1 and Th17, after being antigenically stimulated during the acute infection [60]. A previous study revealed that the influenza virusinfected pigs showed a similar suppression of Tregs in the BAL and lymph nodes and an increased frequency of T-helper cells during the acute phase of infection [23]. Moreover, in some acute infections of mice with lymphocytic choriomeningitis virus (LCMV) and influenza virus, little or no effect on the immune response was observed after the removal of Tregs from mice [61, 62]. Based on the findings from these studies, it can be deduced that Tregs play only a minor role during many acute infections, but further studies are needed to understand the ultimate cause of this decline in the Treg populations, specifically in BAL cells during PRRSV infection.

Cytokine secretion by immune cells plays a major role in protection against invading pathogens or in the induction of pathology [63]. The levels of proinflammatory cytokines have often been associated with the severity of the disease. However, lower mRNA and protein expression levels of proinflammatory cytokines have been associated with protection against viruses in pigs infected with PRRSV strains that typically induce mild to moderate clinical signs [64]. PRRSV has been shown to reduce or suppress IFN- $\alpha$ production during infection [65]. Similarly, in the current study, IFN- $\alpha$ was peripherally suppressed in the infected pigs with increasing viral replication; however, in the BALF, the levels of IFN- $\alpha$ were maintained, even at peak viremia, possibly playing a role in local viral clearance. Similar to our observations, the induction of IFN- $\alpha$ with increasing viremia has also been observed locally in lymphoid tissues and the BALF in PRRSV-infected pigs [66]. Moreover, local induction of the proinflammatory cytokines IL-1 $\beta$ and IL-8 in lymphoid tissues is reportedly linked to the clearance of PRRSV from infected pigs [67]. Similar induction of the proinflammatory cytokines Il- $1 \alpha$, IL- 6 , IL-12, and TNF- $\alpha$

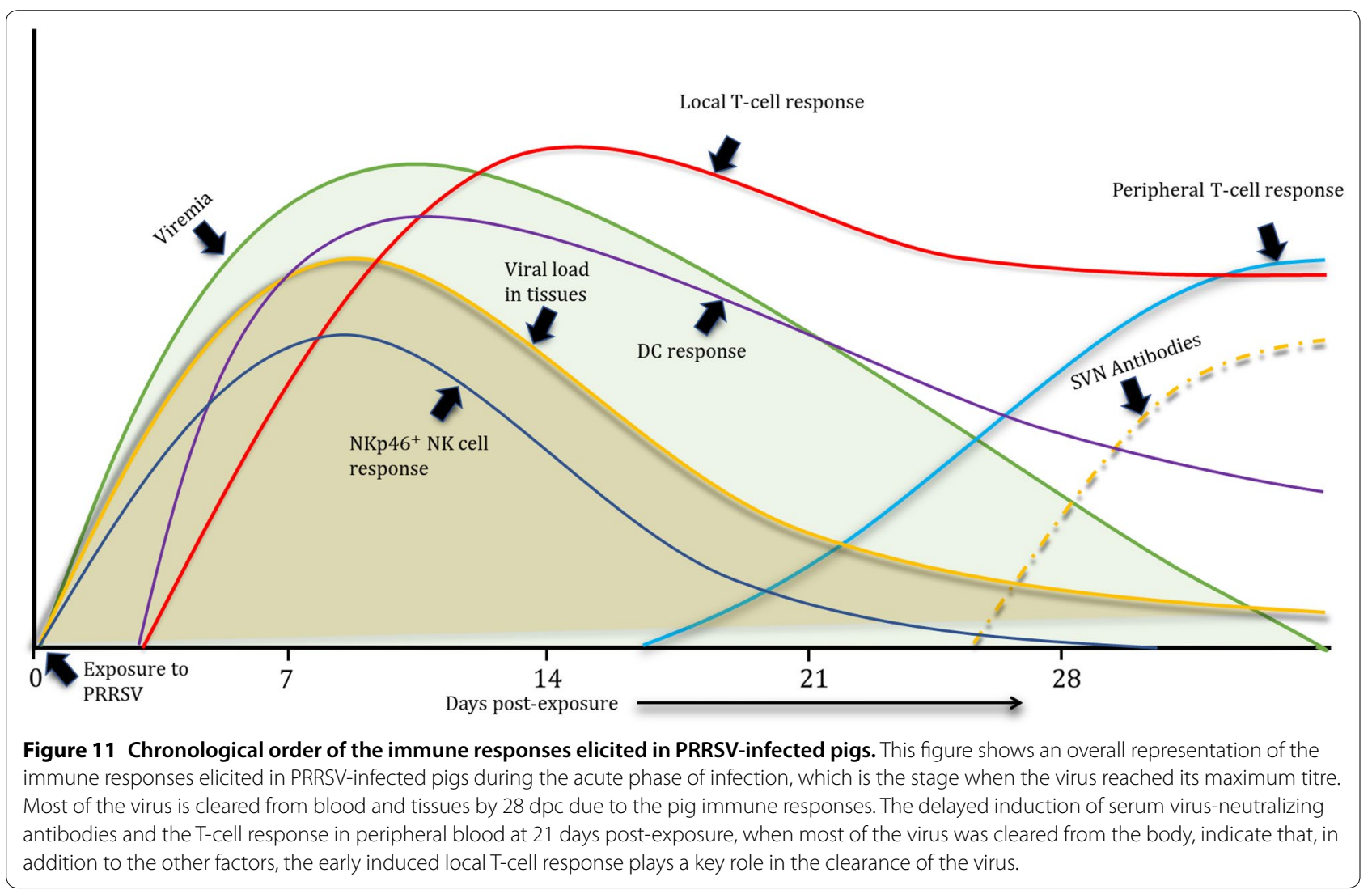


has been observed in local tissues in previous studies [66]. In the current study, the induction of proinflammatory cytokines locally in the BALF at peak viremia could thus be linked to their contribution to the clearance of the virus from the pigs. In contrast, the induction of IL-10 in local tissues during early infection was observed in the present study. The production of IL-10, which has been previously observed, reportedly contributes to the persistence of PRRSV by suppressing the immune response in pigs [68]. However, IL-10 production also protects pigs from the tissue damage caused by proinflammatory cytokine overexpression [14]. Tregs are thought to produce IL-10, but in the current study, the Treg frequencies did not change significantly. However, in addition to Tregs, monocytes, Th2 cells, mast cells and B cells are also known sources of IL-10 [69]. Consequently, measuring the systemic cytokine response might not provide a full picture of the protective events orchestrated by cytokines locally in the lungs of PRRSV-infected pigs.

In conclusion, the early stimulation of the $\mathrm{DC} / \mathrm{mac}-$ rophage frequencies coincided with the induction of a protective T-cell response in local lymphoid tissues and lung parenchyma, which are known sites of PRRSV replication. Moreover, the local proinflammatory cytokine responses at peak viremia augmented the clearance of the virus from the infected pigs. A temporal sequence of immunobiological events after PRRSV infection in pigs is proposed in Figure 11, and the observed schematic suggests that local $\mathrm{T}$ lymphocytes might play an important role in the clearance of the virus from pigs during the acute phase of infection. In addition, early NK cell induction and delayed $\mathrm{T}$-cell responses in peripheral blood were also perceived, and these might play a complementary role in viral clearance. Future studies are needed to further elucidate and refine the understanding of the anti-PRRSV immune response in pigs, and these future studies should primarily focus on obtaining a better understanding of and deciphering the local immune responses with the aim of developing an effective strategy to restrain the virus.

\section{Supplementary information}

Supplementary information accompanies this paper at https://doi. org/10.1186/s13567-020-00789-7.

Additional file 1. List of antibodies used in the flow cytometry analysis.

Additional file 2. Figures indicating the gating strategies used for various cell subsets in the flow cytometric analysis.

Additional file 3. Tabular representation of the percentages of various cell subsets in the PBMC, lung, BAL and BLN samples from infected and uninfected pigs.

\section{Abbreviations}

ADWG: average daily weight gain; AMs: alveolar macrophages; BAL: bronchoalveolar lavage; BALF: bronchoalveolar lavage fluid; BLNs: bronchial lymph nodes; $\mathrm{CDC}$ 1s: conventional dendritic cells $1 ; \mathrm{CDC} 2 \mathrm{~s}$ : conventional dendritic cells 2; CPE: cytopathic effect; DMEM: Dulbecco's modified Eagle's medium; $\mathrm{dpc}$ : days post-challenge; FACS: fluorescence-activated cell sorting; FFN: fluorescent focus neutralization; FoxP3: forkhead box P3; FFU: fluorescent focus unit; IFN: interferon; IL: interleukin; MHC: major histocompatibility complex; moDCs: monocyte-derived dendritic cells; moM $\phi$ s: monocyte-derived macrophages; PRRSV: porcine reproductive and respiratory syndrome virus; PRRS porcine reproductive and respiratory syndrome; PBMCs: peripheral blood mononuclear cells; PBS: phosphate-buffered saline; PI: propidium iodide; RTQPCR: quantitative real-time reverse transcription PCR; ELISA: enzyme-linked immunosorbent assay; RPMI: Roswell Park Memorial Institute; SVN: serum virus-neutralizing; TNF-a: tumour necrosis factor-alpha; mAbs: monoclonal antibodies; RBCs: red blood cells; TCID: tissue culture infective dose; Th1:T helper 1; Th17: T helper 17; CTLs: cytotoxic T lymphocytes; Tregs: regulatory T cells.

\section{Acknowledgements}

The authors are pleased to acknowledge the undergraduates at the College of Veterinary Medicine and the laboratory technicians at the Veterinary Diagnostic Center of Jeonbuk National University (JBNU) for their constant assistance throughout the study.

\section{Authors' contributions}

SN performed the experiments, analysed the data and drafted the manuscript: AK performed the experiments and helped with the data analysis; CGJ, SG, SUSM, SIL, JHP and SCK helped with the animal experiments and laboratory tests; MSY and BK were involved in the animal experiments, including the histopathology and post-mortem examinations; SML and WIK participated in the animal experiments, helped with the data analysis and contributed to the drafting of the manuscript; and BK, CKP, SML and WIK conceived and coordinated the study. All authors read and approved the final manuscript.

\section{Funding}

This work was supported by grants from the Next-Generation BioGreen 21 Program (PJ01 181601), the Co-operative Research Program for Agriculture, Science and Technology Development (PJ01261201) of the Rural Development Administration, and the Technology Development Program for Bio-industry (315029-3) of the Ministry of Food, Agriculture, Forestry and Fisheries in the Republic of Korea.

\section{Availability of data and materials}

All the data generated or analysed during the study are included in this published article. The datasets used and/or analysed during the present research project are available from the corresponding author upon reasonable request.

\section{Ethics approval and consent to participate}

The animal experiment protocol was approved by the Jeonbuk National University Institutional Animal Care and Use Committee (approval number 2016-0043) and performed in accordance with the guidelines and regulations detailed by the committee.

\section{Competing interests}

The authors declare that they have no competing interests.

\section{Author details \\ ${ }^{1}$ College of Veterinary Medicine, Jeonbuk National University, Iksan, South Korea. ${ }^{2}$ Department of Pathology, Faculty of Animal Science and Veterinary Medicine, Sher-e-Bangla Agricultural University, Dhaka 1207, Bangladesh. ${ }^{3}$ Division of Biotechnology, Advanced Institute of Environment and Biosci- ence, College of Environmental \& Biosource Science, Jeonbuk National Univer- sity, Iksan, South Korea. ${ }^{4}$ College of Veterinary Medicine, Kyungpook National University, Daegu, South Korea.}

Received: 1 December 2019 Accepted: 26 March 2020

Published online: 13 May 2020 


\section{References}

1. Benfield DA, Nelson E, Collins JE, Harris L, Goyal SM, Robison D, Christianson WT, Morrison RB, Gorcyca D, Chladek D (1992) Characterization of swine infertility and respiratory syndrome (SIRS) virus (isolate ATCC VR-2332). J Vet Diagn Invest 4:127-133

2. Pileri E, Mateu E (2016) Review on the transmission porcine reproductive and respiratory syndrome virus between pigs and farms and impact on vaccination. Vet Res 47:108

3. Wills RW, Doster AR, Galeota JA, Sur JH, Osorio FA (2003) Duration of infection and proportion of pigs persistently infected with porcine reproductive and respiratory syndrome virus. J Clin Microbiol 41:58-62

4. Diaz I, Gimeno M, Darwich L, Navarro N, Kuzemtseva L, Lopez S, Galindo I, Segales J, Martin M, Pujols J, Mateu E (2012) Characterization of homologous and heterologous adaptive immune responses in porcine reproductive and respiratory syndrome virus infection. Vet Res 43:30

5. van der Linden IF, Voermans JJ, van der Linde-Bril EM, Bianchi AT, Steverink PJ (2003) Virological kinetics and immunological responses to a porcine reproductive and respiratory syndrome virus infection of pigs at different ages. Vaccine 21:1952-1957

6. Done SH, Paton DJ (1995) Porcine reproductive and respiratory syndrome: clinical disease, pathology and immunosuppression. Vet Rec 136:32-35

7. Manickam C, Dwivedi V, Patterson R, Papenfuss T, Renukaradhya GJ (2013) Porcine reproductive and respiratory syndrome virus induces pronounced immune modulatory responses at mucosal tissues in the parental vaccine strain VR2332 infected pigs. Vet Microbiol 162:68-77

8. Bordet $E$, Blanc F, Tiret M, Crisci E, Bouguyon E, Renson P, Maisonnasse P, Bourge M, Leplat JJ, Giuffra E, Jouneau L, Schwartz-Cornil I, Bourry O, Bertho N (2018) Porcine reproductive and respiratory syndrome virus type 1.3 Lena triggers conventional dendritic cells 1 activation and T helper 1 immune response without infecting dendritic cells. Front Immunol 9:2299

9. Wesley RD, Lager KM, Kehrli ME Jr (2006) Infection with porcine reproductive and respiratory syndrome virus stimulates an early gamma interferon response in the serum of pigs. Can J Vet Res 70:176-182

10. Maisonnasse P, Bouguyon E, Piton G, Ezquerra A, Urien C, Deloizy C, Bourge M, Leplat JJ, Simon G, Chevalier C, Vincent-Naulleau S, Crisci E, Montoya M, Schwartz-Cornil I, Bertho N (2016) The respiratory DC/ macrophage network at steady-state and upon influenza infection in the swine biomedical model. Mucosal Immunol 9:835-849

11. Maisonnasse P, Bordet E, Bouguyon E, Bertho N (2016) Broncho alveolar dendritic cells and macrophages are highly similar to their interstitial counterparts. PLoS One 11:e0167315

12. Loving CL, Osorio FA, Murtaugh MP, Zuckermann FA (2015) Innate and adaptive immunity against porcine reproductive and respiratory syndrome virus. Vet Immunol Immunopathol 167:1-14

13. Van Reeth K, Van Gucht S, Pensaert M (2002) In vivo studies on cytokine involvement during acute viral respiratory disease of swine: troublesome but rewarding. Vet Immunol Immunopathol 87:161-168

14. Iyer SS, Cheng G (2012) Role of interleukin 10 transcriptional regulation in inflammation and autoimmune disease. Crit Rev Immunol 32:23-63

15. Baarsch MJ, Scamurra RW, Burger K, Foss DL, Maheswaran SK, Murtaugh MP (1995) Inflammatory cytokine expression in swine experimentally infected with Actinobacillus pleuropneumoniae. Infect Immun 63:3587-3594

16. Conn CA, McClellan JL, Maassab HF, Smitka CW, Majde JA, Kluger MJ (1995) Cytokines and the acute phase response to influenza virus in mice. Am J Physiol 268:R78-R84

17. Kim HS, Kwang J, Yoon IJ, Joo HS, Frey ML (1993) Enhanced replication of porcine reproductive and respiratory syndrome (PRRS) virus in a homogeneous subpopulation of MA-104 cell line. Arch Virol 133:477-483

18. Greig A (1975) The use of a microtitration technique for the routine assay of African swine fever virus. Arch Virol 47:287-289

19. Reed LJ, Muench H (1938) A simple method of estimating fifty per cent endpoints. Am J Epidemiol 27:493-497

20. Kim WI, Kim JJ, Cha SH, Yoon KJ (2008) Different biological characteristics of wild-type porcine reproductive and respiratory syndrome viruses and vaccine viruses and identification of the corresponding genetic determinants. J Clin Microbiol 46:1758-1768

21. Basta S, Carrasco CP, Knoetig SM, Rigden RC, Gerber H, Summerfield A, McCullough KC (2000) Porcine alveolar macrophages: poor accessory or effective suppressor cells for T-lymphocytes. Vet Immunol Immunopathol 77:177-190

22. Khatun A, Nazki S, Jeong CG, Gu S, Mattoo SUS, Lee SI, Yang MS, Lim B, Kim KS, Kim B, Lee KT, Park CK, Lee SM, Kim WI (2020) Effect of polymorphisms in porcine guanylate-binding proteins on host resistance to PRRSV infection in experimentally challenged pigs. Vet Res 51:14

23. Khatri M, Dwivedi V, Krakowka S, Manickam C, Ali A, Wang L, Qin Z, Renukaradhya GJ, Lee CW (2010) Swine influenza H1N1 virus induces acute inflammatory immune responses in pig lungs: a potential animal model for human H1N1 influenza virus. J Virol 84:11210-11218

24. Loving CL, Brockmeier SL, Sacco RE (2007) Differential type I interferon activation and susceptibility of dendritic cell populations to porcine arterivirus. Immunology 120:217-229

25. Mair KH, Essler SE, Patzl M, Storset AK, Saalmuller A, Gerner W (2012) NKp46 expression discriminates porcine NK cells with different functional properties. Eur J Immunol 42:1261-1271

26. Mair KH, Mullebner A, Essler SE, Duvigneau JC, Storset AK, Saalmuller A, Gerner W (2013) Porcine CD8alphadim/-NKp46high NK cells are in a highly activated state. Vet Res 44:13

27. Silva-Campa E, Mata-Haro V, Mateu E, Hernandez J (2012) Porcine reproductive and respiratory syndrome virus induces CD4+ CD8+ CD25+ Foxp3+ regulatory T cells (Tregs). Virology 430:73-80

28. Karlsson F, Hassan-Zahraee M (2015) Quantification of Th1 and Th17 cells with intracellular staining following PMA/ionomycin stimulation. Curr Protoc Cytom 71:6.35.1-6.35.7

29. Shabir N, Khatun A, Nazki S, Gu S, Lee SM, Hur TY, Yang MS, Kim B, Kim WI (2018) In vitro immune responses of porcine alveolar macrophages reflect host immune responses against porcine reproductive and respiratory syndrome viruses. BMC Vet Res 14:380

30. Won JH, Goldberger O, Shen-Orr SS, Davis MM, Olshen RA (2012) Significance analysis of xMap cytokine bead arrays. Proc Natl Acad Sci U S A 109:2848-2853

31. Toka FN, Golde WT (2013) Cell mediated innate responses of cattle and swine are diverse during foot-and-mouth disease virus (FMDV) infection: a unique landscape of innate immunity. Immunol Lett 152:135-143

32. Welch SK, Calvert JG (2010) A brief review of CD163 and its role in PRRSV infection. Virus Res 154:98-103

33. Van Gorp H, Van Breedam W, Delputte PL, Nauwynck HJ (2008) Sialoadhesin and CD163 join forces during entry of the porcine reproductive and respiratory syndrome virus. J Gen Virol 89:2943-2953

34. Davis MM, Bjorkman PJ (1988) T-cell antigen receptor genes and T-cell recognition. Nature 334:395-402

35. Daar AS, Fuggle SV, Fabre JW, Ting A, Morris PJ (1984) The detailed distribution of MHC Class II antigens in normal human organs. Transplantation 38:293-298

36. Wongyanin P, Buranapraditkun S, Chokeshai-Usaha K, Thanawonguwech R, Suradhat S (2010) Induction of inducible CD4+ CD25+ Foxp3 + regulatory T lymphocytes by porcine reproductive and respiratory syndrome virus (PRRSV). Vet Immunol Immunopathol 133:170-182

37. Silva-Campa E, Flores-Mendoza L, Resendiz M, Pinelli-Saavedra A, MataHaro V, Mwangi W, Hernandez J (2009) Induction of T helper 3 regulatory cells by dendritic cells infected with porcine reproductive and respiratory syndrome virus. Virology 387:373-379

38. Kaser T, Gerner W, Hammer SE, Patzl M, Saalmuller A (2008) Phenotypic and functional characterisation of porcine CD4(+)CD25(high) regulatory T cells. Vet Immunol Immunopathol 122:153-158

39. Rossow KD, Collins JE, Goyal SM, Nelson EA, Christopher-Hennings J, Benfield DA (1995) Pathogenesis of porcine reproductive and respiratory syndrome virus infection in gnotobiotic pigs. Vet Pathol 32:361-373

40. Cooper VL, Doster AR, Hesse RA, Harris NB (1995) Porcine reproductive and respiratory syndrome: NEB-1 PRRSV infection did not potentiate bacterial pathogens. J Vet Diagn Invest 7:313-320

41. Opriessnig T, Halbur PG, Yoon KJ, Pogranichniy RM, Harmon KM, Evans R, Key KF, Pallares FJ, Thomas P, Meng XJ (2002) Comparison of molecular and biological characteristics of a modified live porcine reproductive and respiratory syndrome virus (PRRSV) vaccine (ingelvac PRRS MLV), the parent strain of the vaccine (ATCC VR2332), ATCC VR2385, and two recent field isolates of PRRSV. J Virol 76:11837-11844 
42. Lopez OJ, Oliveira MF, Garcia EA, Kwon BJ, Doster A, Osorio FA (2007) Protection against porcine reproductive and respiratory syndrome virus (PRRSV) infection through passive transfer of PRRSV-neutralizing antibodies is dose dependent. Clin Vaccine Immunol 14:269-275

43. Rahe MC, Murtaugh MP (2017) Mechanisms of adaptive immunity to porcine reproductive and respiratory syndrome virus. Viruses 9:E148

44. Lunney JK, Fang Y, Ladinig A, Chen N, Li Y, Rowland B, Renukaradhya GJ (2016) Porcine reproductive and respiratory syndrome virus (PRRSV): pathogenesis and interaction with the immune system. Annu Rev Anim Biosci 4:129-154

45. Renukaradhya GJ, Alekseev K, Jung K, Fang Y, Saif LJ (2010) Porcine reproductive and respiratory syndrome virus-induced immunosuppression exacerbates the inflammatory response to porcine respiratory coronavirus in pigs. Viral Immunol 23:457-466

46. Mair KH, Stadler M, Talker SC, Forberg H, Storset AK, Mullebner A, Duvigneau JC, Hammer SE, Saalmuller A, Gerner W (2016) Porcine CD3(+) NKp46(+) lymphocytes have NK-cell characteristics and are present in increased frequencies in the lungs of influenza-infected animals. Front Immunol 7:263

47. Resendiz M, Valenzuela O, Hernandez J (2018) Response of the CDC1 and CDC2 subtypes of tracheal dendritic cells to porcine reproductive and respiratory syndrome virus. Vet Microbiol 223:27-33

48. Renson P, Rose N, Le Dimna M, Mahe S, Keranflec'h A, Paboeuf F, Belloc C, Le Potier MF, Bourry O (2017) Dynamic changes in bronchoalveolar macrophages and cytokines during infection of pigs with a highly or low pathogenic genotype 1 PRRSV strain. Vet Res 48:15

49. Park JY, Kim HS, Seo SH (2008) Characterization of interaction between porcine reproductive and respiratory syndrome virus and porcine dendritic cells. J Microbiol Biotechnol 18:1709-1716

50. Martin-Fontecha A, Thomsen LL, Brett S, Gerard C, Lipp M, Lanzavecchia A, Sallusto $F(2004)$ Induced recruitment of NK cells to lymph nodes provides IFN-gamma for $\mathrm{T}(\mathrm{H}) 1$ priming. Nat Immunol 5:1260-1265

51. Munz C, Steinman RM, Fujii S (2005) Dendritic cell maturation by innate lymphocytes: coordinated stimulation of innate and adaptive immunity. J Exp Med 202:203-207

52. Rosendahl Huber S, van Beek J, de Jonge J, Luytjes W, van Baarle D (2014) $T$ cell responses to viral infections - opportunities for peptide vaccination. Front Immunol 5:171

53. Graham MB, Braciale TJ (1997) Resistance to and recovery from lethal influenza virus infection in B lymphocyte-deficient mice. J Exp Med 186:2063-2068

54. Heidema J, Lukens MV, van Maren WW, van Dijk ME, Otten HG, van Vught AJ, van der Werff DB, van Gestel SJ, Semple MG, Smyth RL, Kimpen JL, van Bleek GM (2007) CD8+ T cell responses in bronchoalveolar lavage fluid and peripheral blood mononuclear cells of infants with severe primary respiratory syncytial virus infections. J Immunol 179:8410-8417

55. Kick AR, Amaral AF, Cortes LM, Fogle JE, Crisci E, Almond GW, Kaser T (2019) The T-cell response to type 2 porcine reproductive and respiratory syndrome virus (PRRSV). Viruses 11:E796

56. Bystrom J, Al-Adhoubi N, Al-Bogami M, Jawad AS, Mageed RA (2013) Th17 lymphocytes in respiratory syncytial virus infection. Viruses 5:777-791
57. Sanchez AM, Zhu J, Huang X, Yang Y (2012) The development and function of memory regulatory $T$ cells after acute viral infections. J Immunol 189:2805-2814

58. Nedumpun T, Sirisereewan C, Thanmuan C, Techapongtada P, Puntarotairung R, Naraprasertkul S, Thanawongnuwech R, Suradhat S (2018) Induction of porcine reproductive and respiratory syndrome virus (PRRSV)-specific regulatory T lymphocytes (Treg) in the lungs and tracheobronchial lymph nodes of PRRSV-infected pigs. Vet Microbiol 216:13-19

59. Silva-Campa E, Cordoba L, Fraile L, Flores-Mendoza L, Montoya M, Hernandez J (2010) European genotype of porcine reproductive and respiratory syndrome (PRRSV) infects monocyte-derived dendritic cells but does not induce Treg cells. Virology 396:264-271

60. DuPage M, Bluestone JA (2016) Harnessing the plasticity of CD4(+) T cells to treat immune-mediated disease. Nat Rev Immunol 16:149-163

61. Betts RJ, Ho AW, Kemeny DM (2011) Partial depletion of natural CD4(+) $\mathrm{CD} 25(+)$ regulatory $T$ cells with anti-CD25 antibody does not alter the course of acute influenza A virus infection. PLoS One 6:e27849

62. Veiga-Parga T, Sehrawat S, Rouse BT (2013) Role of regulatory T cells during virus infection. Immunol Rev 255:182-196

63. van Reeth K, Nauwynck H (2000) Proinflammatory cytokines and viral respiratory disease in pigs. Vet Res 31:187-213

64. Thanawongnuwech R, Young TF, Thacker BJ, Thacker EL (2001) Differential production of proinflammatory cytokines: in vitro PRRSV and Mycoplasma hyopneumoniae co-infection model. Vet Immunol Immunopathol 79:115-127

65. Calzada-Nova G, Schnitzlein WM, Husmann RJ, Zuckermann FA (2011) North American porcine reproductive and respiratory syndrome viruses inhibit type I interferon production by plasmacytoid dendritic cells. J Virol 85:2703-2713

66. Barranco I, Gomez-Laguna J, Rodriguez-Gomez IM, Quereda JJ, Salguero FJ, Pallares FJ, Carrasco L (2012) Immunohistochemical expression of IL-12, IL-10, IFN-alpha and IFN-gamma in lymphoid organs of porcine reproductive and respiratory syndrome virus-infected pigs. Vet Immunol Immunopathol 149:262-271

67. Lunney JK, Fritz ER, Reecy JM, Kuhar D, Prucnal E, Molina R, ChristopherHennings J, Zimmerman J, Rowland RR (2010) Interleukin-8, interleukin1 beta, and interferon-gamma levels are linked to PRRS virus clearance. Viral Immunol 23:127-134

68. Song S, Bi J, Wang D, Fang L, Zhang L, Li F, Chen H, Xiao S (2013) Porcine reproductive and respiratory syndrome virus infection activates IL-10 production through NF-kappaB and p38 MAPK pathways in porcine alveolar macrophages. Dev Comp Immunol 39:265-272

69. Moore KW, de Waal Malefyt R, Coffman RL, O'Garra A (2001) Interleukin-10 and the interleukin-10 receptor. Annu Rev Immunol 19:683-765

\section{Publisher's Note}

Springer Nature remains neutral with regard to jurisdictional claims in published maps and institutional affiliations.
Ready to submit your research? Choose BMC and benefit from:

- fast, convenient online submission

- thorough peer review by experienced researchers in your field

- rapid publication on acceptance

- support for research data, including large and complex data types

- gold Open Access which fosters wider collaboration and increased citations

- maximum visibility for your research: over 100M website views per year

At BMC, research is always in progress.

Learn more biomedcentral.com/submissions 